MaŁgorZata GuMPER

ORCID 0000-0003-4715-0447

Uniwersytet im. Adama Mickiewicza

$w$ Poznaniu

\title{
POLSKO-LITEWSKIE DZIEDZICTWO KULTUROWE \\ - RÓŻNICE W ŚWIADOMOŚCI SPOŁECZNEJ. PERSPEKTYWY ZBLIŻENIA DZIĘKI WSPÓLNYM BOHATEROM NARODOWYM NA PRZYKŁADZIE MICHAŁA KLEOFASA OGIŃSKIEGO
}

\begin{abstract}
AвSTRAct. Gumper Małgorzata, Polsko-litewskie dziedzictwo kulturowe - różnice w świadomości społecznej. Perspektywy zbliżenia dzięki wspólnym bohaterom narodowym na przykładzie Michała Kleofasa Ogińskiego [Polish-Lithuanian Cultural Heritage - Differences in Social Awareness. Perspectives of Rapprochement by Common National Heroes - a Case Study of Michał Kleofas Ogiński]. Studia Edukacyjne nr 60, 2021, Poznań 2021, pp. 231-261. Adam Mickiewicz University Press. ISSN 1233-6688. DOI: $10.14746 /$ se.2021.60.13

The uncomfortable situation of Poles in Lithuania is, among other things, the effect of Lithuanian historical education. Excerpts from the textbook on the history of Lithuania show diametrical differences in contemporary ideas about the past of both nations. Shared heroes are useful to overcome prejudices of the previous century (which affect the image of 1385-1795). One of them is Michał Kleofas Ogiński, Lithuanian nobleman, a political activist during the last years of the Polish-Lithuanian Commonwealth and two decades after its collapse. He has the rank of a great national hero in Lithuania and Belarus but is valued in Poland above all because of his piano compositions. The analysis of fragments of his work Memoirs about Poland and Poles helps us to regard a representative of the noble nation from a different perspective. It makes us aware of the cohesion of Polish and Lithuanian national identity at the turn of the 19th century, helps us to appreciate the heritage of the past and offers a chance to build positive relations between us. Rectifying a distorted vision of history is a prospect for a mature partnership now and in the future.
\end{abstract}

Key words: Michał Kleofas Ogiński, Polish-Lithuanian Commonwealth, Polish-Lithuanian heritage, cultural binder, cultural rehabilitation, hero, national identity

\section{Wstęp}

Zdajemy sobie sprawę, że istniejący współcześnie dyskurs społeczny na temat stosunków polsko-litewskich przejawia wyraźne tendencje do depre- 
cjacji. Bezpośrednio wynika to ze zdominowania zagadnienia przez wątki koniunkturalne i nurty polityczne, przy jednoczesnym, niemal całkowitym wykluczeniu spoiwa kulturowego z obszarów pamięci historycznej. Nie jest to zjawisko, które per se miałoby niepokoić obserwatora, bowiem jego powszechność potwierdza się we wszystkich krajach współczesnego świata. Problematyczność napotykamy dopiero na etapie analizy czynników pośrednich, oddziałujących przez bardzo długi okres, i odciskających swe piętno na stosunkach współczesnych. Jeżeli bowiem pragniemy wyprowadzać badania nad aktualną świadomością społeczną z wiedzy o przeszłości (a jako historycy czy kulturoznawcy nie rezygnujemy z tego schematu badawczego), to $\mathrm{w}$ przypadku dziejów omawianych państw doświadczymy specyficznego dysonansu poznawczego. Z jednej strony natrafiamy na wyraźną sprzeczność dążeń Polski i Litwy w poprzednim stuleciu, z drugiej - na imponujące dziedzictwo minionej wspólnoty ${ }^{1}$. W tej perspektywie powszechność występowania podobnych zjawisk na świecie przestaje być oczywista, a nawet zostaje wykluczona, przez wzgląd na specyfikę powiązań wspomnianych podmiotów na przestrzeni czterech wieków. Układy te ewoluowały, by w procesie dynamicznych przemian, burzliwych wzlotów i upadków zbudować Rzeczpospolitą Obojga Narodów. Po tym olbrzymim tworze, którego obywatele zainicjowali szereg reform społecznych i z którego wywodził się pierwszy nowożytny naród szlachecki, zamiast poczucia tożsamości pozostała Polakom i Litwinom obcość kulturowa, wraz ze znacznym zasobem uprzedzeń i niechęci. Powodów takiego stanu rzeczy należy dopatrywać się w odmiennej reinterpretacji przeszłości sprzed 1795 roku przez obydwa państwa, jako reakcji na wydarzenia późniejsze. Przyjrzyjmy się zatem kilku wybranym momentom oraz zjawiskom, które najsilniej zaważyły na powstaniu i utrwaleniu stereotypów pejoratywnych we wzajemnych stosunkach.

\section{Początki rozłamu i utrata poczucia wspólnego dziedzictwa}

Zacząć wypada od zagadnienia spolonizowanej szlachty litewskiej, z położeniem nacisku na słowo p o 1 o n i z a c j a, które współczesna kultura poznająca na Litwie gotowa jest rozumieć analogicznie do germanizacji i ru-

\footnotetext{
${ }^{1}$ Dziedzicami tejże wspólnoty pozostają wszystkie narody współczesne, których przodkowie współtworzyli Rzeczpospolitą Obojga Narodów, a więc Białorusini, Litwini, Ukraińcy i Polacy. W całym artykule stosuję uproszczony schemat omawiania problemu niedocenionego dziedzictwa, skupiając się jedynie na współczesnych relacjach polsko-litewskich. Pozostałych spadkobierców kultury Wielkiego Księstwa Litewskiego zmuszona jestem pozostawić niejako „w domyśle”, ze względu na zawężony temat pracy.
} 
syfikacji, czyli przypisywać omawianemu procesowi cechy celowego, świadomego wynaradawiania. Żenkiewicz zwrócił uwagę na początkową fazę tego zapożyczenia i wynikające z niego konsekwencje, które doszły do głosu w II połowie XIX wieku. Pisze on:

Przez szereg stuleci ukształtowany pogląd tożsamości litewskiej określał mieszkańców Litwy jako obywateli byłego Wielkiego Księstwa Litewskiego, w sferze inteligenckiej całkowicie spolonizowanych ${ }^{2}$.

Dla rodzących się w omawianym okresie na Litwie ruchów narodowych, inicjowanych i modelowanych przez młode pokolenie inteligencji wywodzącej się z warstw chłopskich, podobne wnioski stały się pretekstem do budowania negatywnego obrazu przeszłości szlacheckiej. Czasy unii polsko-litewskiej otrzymały etykietę jednoznacznie szkodliwych dla autentycznego zespolenia narodowego, bazującego na przynależności etnicznej.

Utworzone wówczas Towarzystwo Miłośników Litwy, w latach 18831886 wydawało czasopismo „Auszra” (Jutrzenka), kierowane przez Jonasa Basanavičiusa. Wątek wyzwolenia Litwinów spod ucisku dominacji polskiej kultury był w nim stale obecny. Kształtowały go w dużej mierze poglądy Basanavičiusa na temat niesprawiedliwego przypisywania zasług kulturotwórczych tylko jednej ze stron. Ujawniony w ten sposób trend do rywalizacji o tytuł „strony, która wniosła więcej w układ dwóch narodów" najlepiej oddają słowa twórcy litewskiego ruchu narodowego, będące częścią jego artykułu $\mathrm{w}$ omawianym periodyku:

Polacy twierdzą, że podnieśli, przechowali itd. pamięć naszej przeszłości w swej poezji. Któż jednak, pytam, ułożył owe pieśni z przeszłości Litwy, które rozsławiły imię polskiej poezji w Europie? Odpowiedź jest prosta: Litwini! Adomas Mickevicius, (...), J.I. Krasevskis, T. Lenartovicius, Kotkis (Chodźko), Adincius (Odyniec), Asnykis i wielu, wielu pomniejszych poetów - ma nazwiska litewskie, a nie polskie, pochodzi z Litwy, a w ich żyłach płynie litewska krew. Jeśli nawet pisali o przeszłości swej ukochanej Litwy nie po litewsku, to winny jest temu polski wpływ na sprawy literackie (...). (...) Litwini dali Polakom dynastię Jagiellonów, którzy wynieśli dzieje polskie na taką wysokość, na jaką Polacy sami nigdy wznieść się nie byliby zdolni. Stąd też jeśli dzisiaj Polacy przechwalają się, że my Litwini, zawdzięczamy im to, czym jesteśmy, to jest to $\mathrm{z}$ ich strony haniebne i godne nagany kłamstwo, gdyż jak widzieliśmy, to nie Polacy Litwinom, ale Litwini Polakom dali wiele dobrego ${ }^{3}$.

Kierunek wyraźnie antypolski w dalszej przyszłości utrudnił realizację niektórych celów „Auszry”. Mackiewicz syntetyzuje, iż

2 J. Żenkiewicz, Litwa na przestrzeni wieków i jej powiązania z Polską, Toruń 2001, s. 122.

3 J. Basanavičius, "Aušra" i "Dziennik Poznański”, [w:] B. Kalęba, M. Zaczyński, W kręgu sporów polsko-litewskich na przełomie XIX i XX wieku. Wybór materiałów, tom 1, Kraków 2004, s. 11. 
najważniejszym zadaniem, jakie postawili sobie wydawcy pierwszej, w pełni niezależnej litewskiej gazety było rozbudzenie ducha narodowego, uświadomienie Litwinom dawnej potęgi państwa litewskiego, przypomnienie bogatych tradycji narodu, odrębności języka i obyczajów, a także wielowiekowej kultury ${ }^{4}$.

Tymczasem, wykluczenie pozytywnych odniesień do wspólnoty przedrozbiorowej zmuszało do formułowania zarzutów bazujących na obcości, które zdegradowały okres unii polsko-litewskiej, wzmacniając poczucie antagonizmu. Wrogość wobec współtwórców utraconego w 1795 roku państwa odcisnęła swe piętno na stosunku przyszłych pokoleń do tego zagadnienia, w zasadzie pozbawiając Litwinów uczucia dumy czy zadowolenia z faktu dziedzictwa Rzeczpospolitą Obojga Narodów.

$\mathrm{Na}$ tendencyjność niektórych treści zamieszczanych na kartach „Auszry” zareagował „Dziennik Poznański”, wystosowawszy szereg artykułów w obronie wartości wspólnego dziedzictwa i jego znaczenia dla przetrwania zaborów. Niestety, także polscy autorzy nie zrezygnowali z kierunku przypisywania jednej ze stron - rzecz jasna „swojej” - dziejowej wyższości. Między wydawcami obu gazet, w latach 1883-1884, wywiązała się burzliwa dyskusja korespondencyjna. Autor artykułu zatytułowanego Objaw litewski z „Dziennika Poznańskiego", komentujący pojawienie się „Auszry”, popełnił na wstępie wyraźne faux pas, pisząc:

Litwa Kiejstutów i Mindowów, Litwa owego osobnego plemienia i języka (...), zawdzięcza swój byt dzisiejszy i pamięć swego istnienia, swą obecność w panteonie narodów i ludów cywilizacji - Polakom i jedynie tylko Polakom.

Polacy przynieśli jej światło chrześcijaństwa, nie tykając jak krzyżactwo jej języka. Polacy uświetnili jej przeszłość we własnej swej narodowej poezji. Słowem, wszystko, czym są i że są zawdzięcza zacny, sympatyczny nam tyle żywioł litewski - Polsce i Polakom.(...)

Dziś pojmujemy Litwinów p o l i t y c z n i e i n a r o d o w o - jako Polaków inaczej mówiących (...). (...) Nie przeciw P o la k o m tedy też zwracać się należy Litwie, skoro budząc się dzisiaj z uśpienia i korzystając sama ze środków dzisiejszej cywilizacji, zaczyna wydawać we własnym języku czasopisma i przemawiać $\mathrm{w}$ interesie ocalenia własnego żywiołu.

Uwagi te nasuwają nam się na myśl z powodu wychodzącego od miesiąca maja r.b. w pruskim mieście Ragnecie miesięcznika literackiego pod tyt. „Auszra”. (...) Niestety przekonaliśmy się zeń, że korzystając z moralnych dobrodziejstw wspólności polsko-litewskiej, (...) ragnecka „Auszra” wzięła sobie za równie nieszlachetne, jak bezskuteczne zadanie rozbudzenia patriotyzmu litewskiego przez podszczuwanie go przeciw Polakom. (...)

${ }^{4}$ M. Mackiewicz, Obraz litewskiego odrodzenia narodowego w publicystyce "Auszry" w latach 1883-1886, [w:] Tendencje rozwojowe myśli politycznej i prawnej, red. M. Maciejewski, M. Marszał, M. Sadowski, Wrocław 2014, s. 423, http://www.repozytorium.uni.wroc.pl/dlibra /publication/46592/edition/46519/content?ref=desc, [dostęp: 8.02.2019, godz. 10:05]. 
Tylko wspólna zgoda Litwy z Polską może być dla pierwszej i na p r z y s z ł o ść puklerzem bezpieczeństwa, jak nim była w p r z e s z ł o ś c i ${ }^{5}$.

Jak widzimy, za utwierdzanie nowoczesnego narodu litewskiego w poczuciu zniewolenia przez polską „wyższość” odpowiadały niejednokrotnie poczynania obu zwaśnionych stron. Zasadniczo, ostatnia dekada XIX wieku przyniosła wykrystalizowanie się dążeń narodowowyzwoleńczych i odpowiadających im kierunków politycznych. W nurcie narodowo-klerykalnym ${ }^{6}$ bardzo silne było przesłanie antypolskie, między innymi czasopismo „Tevynes Sargas" (Stróż Ojczyzny) oskarżało ziemian polskich o zwyrodnienie, opisując tę grupę jako wrogich Litwinom „polonizatorów"7. Nieco lepiej dla Polaków zapowiadały się dążenia ruchu narodowo-demokratycznego ${ }^{8}$, jednak kiedy w 1902 roku utworzył on Litewską Demokratyczną Partię, do głosu doszły hasła nacjonalistyczne („Litwa dla Litwinów”9). W ten sposób przełom XVIII i XIX wieku wyznaczył mentalności społecznej na Litwie kierunek przemian jednoznacznie nieprzychylny sentymentom względem przeszłości.

Rozwój piśmiennictwa litewskiego oddziaływał na kształtującą się świadomość chłopów, zarazem autorzy czerpali z ludowej tradycji i kultury wątki do rozbudowy nowego znaczenia pojęcia "naród”. Zniesienie przez Mikołaja II zakazu wydawania dzieł w języku litewskim, które nastąpiło w 1904 roku, umożliwiło rozkwit literatury narodowej. Proces unarodowienia warstwy chłopskiej wiązał się ściśle z rozbudzaniem postaw opozycyjnych wobec stanu szlacheckiego. Poczucie dawnych niesprawiedliwości przeobraziło się, głównie pod wpływem oddziaływania "Auszry”, w niechęć do jego przedstawicieli, utożsamianych z polskością. Tym sposobem konflikt stanowy został przekierowany na rzekomy konflikt narodowy, w którym stroną poszkodowaną byli litewscy chłopi, czyli prawdziwi, rodowici Litwini, zaś agresorem - szlachta polska, lub spolonizowana szlachta litewska, która zatraciła swe dobre cechy z chwilą przyjęcia tożsamości „Polaków”.

Wiek XX miał przynieść największy rozłam w poczuciu wspólnoty polsko-litewskiej. Wzajemna niechęć osiągnęła w czasie jego trwania apogeum. Spośród działających przed I wojną światową litewskich partii politycznych, najbardziej nacjonalistyczny program wysuwali narodowcy pod przewodnictwem Jonasa Basanavičiusa. Aktywny w tym czasie, późniejszy prezydent Republiki Litewskiej, Antanas Smetona, oraz przyszły premier Litwy, Augustinas

${ }^{5}$ Objaw litewski, „Dziennik Poznański” 1883, nr 231, s. 1-2; w: A. Srebrakowski (oprac.), My nie bracia, my sąsiedzi. Polska perspektywa stosunków polsko-litewskich. Wybór tekstów i dokumentów, Wrocław 2013, s. 49-52.

${ }^{6}$ J. Żenkiewicz, Litwa na przestrzeni wieków, s. 125.

7 Tamże.

8 Tamże.

9 Tamże, s. 126. 
Voldemaras, wykładali swe podstawowe założenia o prawie narodu litewskiego do samostanowienia między innymi w czasopismach "Vairas" (Ster), "Vilniaus žinios” (Wieści Wileńskie), ,Viltis" (Nadzieja), ,"Lietuvos ūkininkas” (Litewski gospodarz), czy wydawanym od 1917 roku „Lietuvos aidas” (Echo Litwy). W prowadzonych między 1911 a 1945 rokiem Dziennikach Michała Römera, litewskiego prawnika i sędziego, rektora Uniwersytetu Witolda Wielkiego, wywodzącego się ze spolszczonego rodu szlacheckiego, autor zapisywał swoje spostrzeżenia na temat postaw głównych działaczy ruchu narodowego:

Basanowicz [Basanavičius - przyp. M.G.], mający skądinąd dużo olbrzymiej wagi zasług w sprawie odrodzenia narodowego Litwinów, jest wszakże czystej krwi nacjonalistą. Jest straszliwie podejrzliwy względem wszystkiego co polskie, węszy na każdym kroku niebezpieczeństwo supremacji polskiej, która jest dla niego straszakiem największym. Stąd jego niechęć do języka polskiego, gdy w kółku Litwinów z udziałem takich osób jak ja, używa się języka mieszanego, to litewskiego, to polskiego. Basanowicz unika tendencyjnie języka polskiego i przechodzi raczej na rosyjski, o ile nie mówią po litewsku ${ }^{10}$.

W innym miejscu wzmianka dotyczy osobistych kontaktów i prywatnego konfliktu powstałego na skutek utożsamiania się Römera zarówno z narodowością polską, jak i litewską:

Wieczorem napisałem odpowiedź na ostatnią napaść na mnie redaktora Smetony w „Viltisie”. Środki polemiczne, jakich się Smetona w walce ze mną chwyta, są wstrętnie demagogiczne. Wyrzuca mi urodzenie szlacheckie, niańkę poddaną itp. (...) Dalej Smetona $\mathrm{w}$ drodze insynuacji wmawia mi, że rzekomo jestem przeciwnikiem reagowania Litwinów na wynaradawianie ich przez polonizację. Wreszcie stara się wpoić w swych czytelnikach podejrzenie o mnie jako o rzekomym agencie szlacheckim, który, biorąc lud na lep słodkich słówek, szuka sposobów utrzymania ludu w zależności omalże nie pańszczyźnianej od szlachty i Polaków ${ }^{11}$.

W tym czasie wątek oddzielności narodowej był już w zasadzie mocno osadzony w świadomości społecznej. Powstawały organy dążące do jego utrwalania, jak choćby Litewskie Towarzystwo Naukowe. Znaczną rolę odegrała kontrowersyjna twórczość założyciela Litewskiego Towarzystwa Sztuk Pięknych (1907) Petrasa Rimšy. Podczas jednej z wystaw w Wilnie zaprezentował on swą rzeźbę, zatytułowaną „Walka”, której symbolika unaoczniła problem odnoszenia się młodego narodu litewskiego do przeszłości przedrozbiorowej. W cytowanych już Dziennikach Römera odnajdujemy następujący opis tego dzieła:

Rzeźba przedstawia grupę złożoną z rycerza na koniu, walczącego z orłem jednogłowym. Orzeł, przywalony do ziemi, ze skrzydłami rozpostartymi, wpił się drapież-

${ }^{10}$ Cyt. za: Kurier Wileński, https:/ / kurierwilenski.lt/2017/07/14/korzenie-wspolczesnosci -dzienniki-michala-romera-z-lat-1911-1915/, [dostęp: 7.02.2019, godz. 10:06].

${ }^{11}$ Cyt. za: tamże. 
nym dziobem w gardziel końską; koń przysiada z bólu na tylnych nogach, wspina się i przydeptuje przednimi orła, jeździec zaś z zamachniętym mieczem w ręku gotuje się do zadania ciosu śmiertelnemu ptakowi. Grupa ta symbolizuje oczywiście walkę polsko-litewską, walkę Orła z Pogonią. U dołu grupy, jakby dla podkreślenia symbolu, tarcza z herbami Polski i Litwy - Orłem i Pogonią. Orzeł przedstawiony w postaci napastującego drapieżnika, którego zwycięża wolna rycerska Pogoń (...). Rzeźba ta wywołała oburzenie wśród publiczności polskiej ${ }^{12}$.

Rimša wykonał także inne prace o przekazie antypolskim, motywowane wydarzeniami z XX wieku, takie jak medale upamiętniające zdobycie Wilna przez Polaków, na których Polska przybrała postać między innymi nagiej prostytutki lub świni w rogatywce ${ }^{13}$.

Konflikt o Wileńszczyznę zajmuje szczególne miejsce wśród ważniejszych punktów spornych. Mamy świadomość, że tak zwany bunt Żeligowskiego w październiku 1920 roku i powstanie w konsekwencji Litwy Środkowej, przyłączonej następnie do Polski 18 kwietnia 1922 roku, były i pozostają do dzisiaj najgłębszą raną w pamięci historycznej Litwinów, dotyczącej okresu zdobywania przez nich pełnej niepodległości. Sytuację polityczną w Polsce po I wojnie światowej - zarówno program federalistyczny Piłsudskiego, jak i endecką wizję państwa narodowego - współczesny historyk litewski Zigmantas Kiaupa ocenił jednoznacznie, pisząc:

Oba te poglądy negowały niepodległość Litwy, były oparte na interpretacji dziedzictwa i historii Rzeczypospolitej Obojga Narodów i ignorowały równe prawa dwóch narodów ${ }^{14}$.

Mówiąc o problemie wileńskim, powinniśmy zaakceptować pogląd drugiej strony, która przypisuje omawianemu wydarzeniu rangę polskiej okupacji. Na takie podejście przygotowała Litwinów retoryka narodowa XIX wieku, która wykluczyła postrzeganie poszczególnych terytoriów przez pryzmat dziedzictwa kulturowego. Kiaupa wyjaśnia znaczenie mitu Wilna dla tożsamości litewskiej:

Dla Litwy i Litwinów Wilno było historyczną stolicą, centrum tożsamości narodowej w czasach zaboru rosyjskiego. W 1904 r., gdy został zniesiony zakaz druku (...), Wilno zostało tym centrum, nie zważając na zabór rosyjski i okupację niemiecką - stolicą współczesnego, powstającego narodu litewskiego. Tu w 1905 r. obradował Wielki Sejm Wileński, Rada Litewska/Państwowa Rada Litewska, były powołane pierwsze Gabinety Ministrów. W Wilnie działały organizacje kulturowe. Litewskość powróciła

12 Cyt. za: tamże, godz. 9:51.

13 https://www.ludzkosc.pl/Petras_Rimsa, [dostęp: 7.02.2019, godz. 10:11].

14 Z. Kiaupa, Litwa w dwudziestym wieku. Republika Litewska w latach 1918-1940, Projekt: Historia a teraźniejszość. Dziedzictwo Rzeczpospolitej Obojga Narodów a aktualne stosunki polskolitewskie, Lublin 2012, s. 6. 
do miasta i działała obok instytucji politycznych i kulturowych wspólnot żydowskich, polskich, białoruskich. Wilno było częścią tożsamości litewskiej i bez tego miasta trudno było wyobrazić sobie jednolite państwo. Wilno dla Litwy w życiu codziennym i na arenie międzynarodowej przybrało formę egzystencjalną ${ }^{15}$.

Zauważmy, że Polacy z tamtego okresu nadal określani są mianem obcego agresora, nacierającego z zewnątrz okupanta. Trwałość tego stereotypu potwierdził były prezydent Litwy Vytautas Landsbergis podczas wywiadu udzielanego w czasie trwania Międzynarodowego Przeglądu Filmów „Świat bez wolności", odbywającego się we Wrocławiu w 2016 roku. Tłumaczył wówczas nastawienie współczesne Litwinów wobec Polaków, odnosząc się do różnych momentów historii:

Wilno nigdy nie było częścią Polski i zawsze było centrum Litwy. Wyjątkiem było 17 lat istnienia Litwy Środkowej. Tak zwany bunt Żeligowskiego przypominał rosyjską taktykę w Abchazji albo Osetii Południowej: zająć, a później przyłączyć. W czasie II wojny Wilno wróciło do Litwy, o czym zadecydowali Mołotow i Ribbentrop, potwierdzając prawo Litwy do Wilna. (...) Wilno zostało zagarnięte przez wojsko polskie generała Żeligowskiego, wysłanego tam przez Naczelnika Państwa Józefa Piłsudskiego, który sam sobie taki tytuł nadał. Powiedział on Żeligowskiemu, że nie bierze żadnej odpowiedzialności za jego działania i nie przyzna się do wydania rozkazu, wyrzeknie się go. Celem było zajęcie jak największej ilości ziem. Zresztą, gdy niepodległa Polska została proklamowana w 1918 roku jeszcze przez Radę Regencyjną, to w granicach przed rozbiorami. Być może zamierzali deklarować jak największe państwo, aby później móc jak najwięcej z tego wyciąć. Miejsca dla Litwy tam nie było, choć od lutego 1918 roku Litwa proklamowała niepodległości ze stolicą w Wilnie. Rada Regencyjna zignorowała istnienie państwa litewskiego. Zależało im na Polsce sprzed 1772 roku, gdzie Litwa miała być jedynie prowincją. (...) Piłsudski, wielki polski patriota, przyłączając Wilno to zaprzepaścił. Oczywiście Piłsudski uważany jest w Polsce za bohatera narodowego, ale realia są takie, że popełnił ciężkie błędy. Jego działania przyniosły efekty na krótkim dystansie, bo dostał kawałek Litwy. Na dłuższym już nie, bo zepsuł stosunki polsko-litewskie. Polska nie jest wyłącznie ofiarą, jak to Polacy lubią mówić16.

Dwudziestolecie międzywojenne zdominowała najpierw walka o terytoria, a następnie wzajemna niechęć, ujawniona w całkowitym zerwaniu stosunków politycznych aż do 1938 roku. Musimy pamiętać, że było to szkodliwe dla mentalności obu stron, a z czasem stało się męczącym wyrzutem sumienia. Poetka Kazimiera Iłłakowiczówna (1892-1983) dała wyraz społecznego poczucia straty i utrapienia, utrzymującego się przez cały czas trwania konfliktu, pisząc wiersze, z których przebijał apel o ponowne zjednoczenie narodów w duchu braterstwa. Zdradzają one, jak nienaturalną sytuacją była dla urodzonych na Litwie Polaków anomalia wzajemnych walk polsko-litewskich:

15 Tamże.

${ }^{16}$ Cały wywiad dostępny na stronie: https://nowahistoria.interia.pl/aktualnosci/newsvytautas-landsbergis-pilsudski-to-wasz-bohater-popelnil-jedn,nId,2236986, [dostęp: 7.02.2019, godz. 13:46]. 
Odpoczynek Żeligowskiego ${ }^{17}$ (fragmenty)

A co jeśli droga była mylna, a co jeśli nie dość było Wilna, a co jeśliśmy pokuty byli warci za pół czynu, za Litwy rozdarcie?
Wyzwanie ${ }^{19}$ (fragmenty)

O Litwo, o ojczyzno,

Teraz się do mnie przyznaj!

Niczyją, z gniazda wypchniętą, Tutaj mnie przygarnięto.

(...) Lecą ptaki ze wschodu, zachodu, Pytają, jakiegom rodu.

O Litwo, o ojczyzno,

Teraz się do mnie przyznaj!

\section{Pora się godzic ${ }^{18}$ (fragmenty)}

Pora się godzić, panowie Litwini, wszystko najgorsze już każdy uczynił: szkodził drugiemu, jak tylko potrafił, zmylał historię, męczył geografię. Każdy, jak tylko mógł, dla swej muzyki, przynaglał śpiewać nawet nieboszczyki.

Zbrzydło historii słuchać naszych pieniactw, stoi, pod słońce ręką wzrok ocienia, patrzy po morzach i patrzy po lądach: "Tak oto Polska, tak Litwa wygląda, owa-maleńka, ta wzrostem się piętrzy... Lecz czas osądzi, która z nich jest większa!"

(...) Możeś niewielki naród, lecz wybrany: mową kolebki dosięgasz Iranu, moc twej stałości i wola wytrwania serca porusza, do podziwu skłania... Nikt cię ukorzyć nie chce, nikt ci szkodzić, pora się godzić, litewski narodzie.

Dość po katowsku czyste ręce brudzić! Krew twoja płynie w żyłach wielkich ludzi. Żeś chłopski - bredzą nie wiadomo na co ty, coś wielkością synów twych uszlachcon. Jednego rodu z tobą - bohaterzy, co po Wawelach naszych, Skałkach leżą.

$$
\text { Modlitwa o pokój }{ }^{20} \text { (fragmenty) }
$$

(...) Jeszcze na mnie te zorze dyszą...

Zapach grozy i obcych ziem...

O Boże, napełnij mnie ciszą, Jak pole kwitnącym lnem! ...Jeszcze dusi nie moja nienawiść, Smoczy opar i wyziew trupi...

O Boże, racz nas wybawić

Od zemsty - ślepych i głupich...

(...) O Boże, nienawiść zabliźnij Jak pole - kwitnącym lnem.

${ }^{17}$ K. Iłłakowiczówna, Ballady bohaterskie, Lwów 1934, s. 27, za: K. Szpunar, Kazimiery Iłłakowiczówny dyskurs o utraconej ojczyźnie, [w:] Tematy i konteksty. Pogranicza jako przestrzenie... konfliktów: zło konieczne?, 2017, 7(12), http://ifp.univ.rzeszow.pl/tematy_i_konteksty/tematy_i_konteksty_12/11_szpunar.pdf, [dostęp: 7.02.2019, godz. 22:04].

${ }_{18}$ Wileńskie Rozmaitości, III kwartał 1990, 3, s. 2, http://www.kpbc.ukw.edu.pl/dlibra/ plain-content?id=23060, [dostęp: 7.02.2019, godz. 21:45].

${ }^{19}$ K. Iłłakowiczówna, Stowik litewski, s. 22, za: K. Szpunar, Kazimiery Iłłakowiczówny dyskurs, s. 177.

${ }^{20}$ Tamże, s. 51. 
Okres II wojny światowej okazał się kontynuacją wyniszczającego układu, zaś lata komunizmu całkowicie wyjałowiły oba społeczeństwa z resztek świadomości o znaczeniu czasów przedrozbiorowych. Bolesna świadomość dążeń litewskich i niemieckich do wyniszczenia narodu polskiego, pamięć o masowych pogromach, łapankach i wywozach do obozów zagłady, oraz odwetach organizowanych przez AK (np. wzajemne masakry dokonane w Glinciszkach i Dubinkach w czerwcu $1944 \mathrm{r}^{21}$ ), nie pozwoliła do tej pory $\mathrm{w}$ pełni odrzucić uprzedzeń, które jeszcze $\mathrm{w}$ okresie postkomunistycznym rzutowały na sposób odnoszenia się do przeszłości.

Za przykład tendencyjności w kształtowaniu wyobrażeń o czasach bardzo odległych mogą posłużyć fragmenty z litewskiego podręcznika Historia Litwy. Uświadamiają nam one, jakim manipulacjom poddawano pokolenie Litwinów, którzy obecnie są ludźmi w wieku około 40 lat, a więc aktywnymi politycznie obywatelami oraz wychowawcami swych dzieci. Zauważmy, że przytoczone cytaty dotyczą bardzo wczesnego okresu współpracy polsko-litewskiej, lecz dystans czasowy nie osłabia bynajmniej naznaczenia pejoratywnego, które w 1994 roku (data wydania podręcznika) zataczało nadal coraz szersze kręgi w edukacji historycznej. Choć treść główna informowała o wielu wspólnych przedsięwzięciach, zwycięstwach i osiągnięciach, to wprowadzane w podtekście przesłanie ukierunkowywało myślenie ucznia ku nieufności względem wszystkich unii, które w ostatecznym rozrachunku okazywały się nieopłacalne dla Litwinów, niejednokrotnie przez nieuczciwość Polaków. Fragmenty mające oddziaływać pejoratywnie umieszczono w tabeli $1^{22}$ :

Tabela 1

Wizja wspólnych dziejów Polski i Litwy w podręczniku litewskim dla klas 6 - 7 z 1995 (1994) roku

\begin{tabular}{|c|c|c|}
\hline $\begin{array}{l}\text { Unia w Krewie, } \\
\text { początek rządów } \\
\text { Jagiełły i Witolda }\end{array}$ & $\begin{array}{c}\text { Postawa panów polskich } \\
\text { wobec Litwy oraz dążenia } \\
\text { bojarów litewskich } \\
\text { w okresie poprzedzającym } \\
\text { unię lubelską }\end{array}$ & Unia lubelska i jej skutki \\
\hline $\begin{array}{l}\text { - Podsumowanie lekcji - jeden } \\
\text { z podpunktów odpowiadających } \\
\text { na pytanie: Dlaczego Jagiełto wy- } \\
\text { brat unię z Polską: } \\
\text { - Jagiełte zwabili panowie polscy, którzy } \\
\text { zaproponowali mu koronę króla Polski. } \\
\text { (s. 107) }\end{array}$ & $\begin{array}{l}\text { - Unia horodelska nadała więk- } \\
\text { sza niezależność Litwie. (...) } \\
\text { Panowie polscy postanowi- } \\
\text { li jednak zburzyć państwo } \\
\text { litewskie w inny sposób - } \\
\text { ujednolicić życie wewnętrzne } \\
\text { obydwu krajów. I to zostato } \\
\text { zapoczatkowane. (s. 134) }\end{array}$ & $\begin{array}{l}\text { - Wstęp do tematu Unia lu- } \\
\text { belska z } 1569 \text { r. - Dojrzewa- } \\
\text { nie przestanek unii lubelskiej: } \\
\text { Przypomnij sobie, że układ krewski } \\
\text { (1385) byt niekorzystny dla Litwy } \\
\text { - chociaż państwo litewskie się za- } \\
\text { chowato, lecz potaczyto wieziami } \\
\text { wasalnymi z Królestwem Polskim. } \\
\text { (s. 202) }\end{array}$ \\
\hline
\end{tabular}

${ }^{21}$ J. Żenkiewicz, Litwa na przestrzeni wieków, s. 172.

${ }^{22}$ Wszystkie cytaty zamieszczone w Tabeli 1 . pochodzą z podręcznika: J. Brazauskas, Historia Litwy od czasów najdawniejszych do unii lubelskiej, przekł. Ł. Pocewiczienie, Kowno 1995. $\mathrm{W}$ nawiasach podano numery stron. 
- Najważniejszeprzyczynyuniipolsko-litewskiej:

(...) - Polska pragnęta opanować ziemie Wielkiego Księstwa Litewskiego, szczególnie - bogate Podole i Wotyń (...). (s. 109)

- Unia polsko-litewska została zawarta na skutek przyczyn zewnętrznych. Dwa różne państwa (różniące się ustrojem, kultura) nie mogły istnieć wspólnie, więc $i$ po zawarciu unii w i od t y od ręb n y $\dot{z}$ y w o t. Bojarzy litewscy pojmowali akt krewski jako sojusz dwóch równych państw, zawarty przede wszystkim w celach wojennych. W żadnym wypadku nie zgadzali się na unicestwienie swej państwowości $i$ znalezienie się pod obcymi rządami. (s. 110)

- Pytania i zadania:

4. Co zmuszało Litwę i Polske do zawarcia unii krewskiej?

5. Czy korzystna byta dla Litwy unia krewska? (s. 112)

- Głoszacy wiare katolicka duchowni polscy nie uczyli się języka litewskiego, gardzili nim jako pozostałościa pogaństwa, zmuszali Litwinów do uczenia się języka polskiego. Zatem rozpoczęła się polonizacja kraju litewskiego. (s. 113)

- Jeden ze skutków unii krewskiej: - Litwa stała się wasalem Polski. (s. 114)

- Niektóre pytania, jakie zadają sobie współcześni historycy na temat rządów Jagiełły:

- Czy zawierając unię krewska Jagiełto $z$ dradził Litwinów?

- Czy unia krewska była rzeczywiście korzystna dla obu krajów $i$ zadecydowała o zwycięstwie w bitwie pod Grunwaldem? (s. 114)

- Po bitwie pod Grunwaldem: Szacunek, miano poważnego polityka zyskat té் Jagiełto, już jedynie za to, że przekonat Polaków do walki z Krzyżakami, którzy nie uważali przyszłej bitwy za tak ważna, jak Litwini, gdyż ziemie Pomorza byty już dawno utracone i Polacy z tym sie pogodzili. (s. 131)
- Jednakże Polska prowadziła podstęna politykę wobec Litwy - wykorzystata przerwe $w$ wojnie do przygotowania spisku przeciwko Świdrygielle. (s. 143)

- W owym czasie panowat $w$ Polsce Wtadystaw, starszy syn Jagietty. Większość panów litewskich stale szukata możliwości zerwania zawartego przez Jagiette sojuszu z Polską. (s. 148)

- O okresie rządów Kazimierza Jagiellończyka jako wielkiego księcia litewskiego, przed objęciem przezeń tronu polskiego:

$W$ ciagu siedmioletniego okresu niepodległości Litwe dodatnio oceniono w catej Europie. (s. 149)

- O okresie rządów Kazimierza Jagiellończyka jako króla polskiego:

Panowie litewscy nie byli zadowoleni ze wspólnego władcy Polski i Litwy. (s. 153)

- O rządach Zygmunta I Starego:

Zahamowat on wynaradawianie się $i$ kolonizowanie Litwy - wydat ustawy zakazujące obcokrajowcom Polakom i Rusinom nabywać ziemie na Litwie oraz zajmować stanowiska państwowe. (s. 157, 158)

- Feudałowie polscy, aby uzasadnić posiadane na Litwie prawa, głosili swe wysokie pochodzenie, feudałów litewskich zaś poniżali, że nie sa szlachetnego pochodzenia, nie maja wybitnych przodków. Dlatego ci ostatni pragnęli bronić nie tylko własnych interesów, lecz również interesów Litwy. (s. 180)
- Wstęp do tematu Unia lubelska z 1569 r. - Dojrzewanie przestanek unii lubelskiej: (...) od 1440 r. Litwa będaca w przymierzu, a od 1447 r. - w unii personalnej z Polska, była w rzeczywistości samodzielna. Ma się rozumieć, że Polska nie uznawała jej samodzielności, lecz musiała $z$ nią się liczyć. (s. 202)

- Warunki unii lubelskiej:

(...) Większość bojarów litewskich uważała unię za zwyczajny sojusz wojskowy (...). Jednakże delegacja polska (...) znów wysunęta swój stary projekt - przyłaczenia Litwy do Polski. (...) Szlachta polska w tym czasie przedsięwzięta zgubne dla Litwy środki. (...) Rzeczywiście, delegacja Litwy, jak sama mówiła, czuła się, jakby miata "podcięte skrzydła”, "zagnana w kat". Trzeba jej było tylko podsunać polski projekt $i$ zmusić do złożenia pieczęci. (s. 205)

- J. Chodkiewicz w swym przemówieniu odrzekt: "Niech będzie z tymi pieczeciami tak, jak postanowimy, niech będzie jedna pieczéć". (Tę "jedna" pieczęć można było rozumieć jako w s pól n a, nie zaś „wytącznie polska". Polacy, oczywiście, zrozumieli po swojemu). (s. 206)

- Skutki i znaczenie unii lubelskiej:

Unia lubelska usankcjonowała prawnie status samodzielnej Litwy $w$ sojuszu. Jednakże jeden $z$ członków tego sojuszu był silniejszy (Polska), a drugi - stabszy (Litwa). Politykę państwowa prowadzono zgodnie $z$ interesami Polski. Wtadce wybierali Polacy, a Litwini mogli jedynie aprobować lub nie. Sytuacja Litwy warunkowała jej wybór: aprobowata wybór Polaków, lecz nakłaniata wtadcę do ustęstw. (s. 207) 
W przypadku analiz nowszych podręczników, jak na przykład Istorijos vadovelis 11 klasei, wydanego w Wilnie w 2014 roku, pociesza odstępstwo od tego typu manipulacji. Profesor Łukaszewicz ocenia, iż w przekazie tej książki

brak dokuczliwości, a kwestie sporne autorzy starali się przedstawiać w sposób wyważony i obiektywny, uwzględniający przy tym możliwości percepcyjne młodzieży ${ }^{23}$. Podaje również konkretne przykłady poprawy przesłania dydaktycznego, m.in. fakt, że pisząc o bitwie pod Grunwaldem, autorzy odeszli od powszechnego do niedawna litewskiego przekazu, sugerującego, iż zwycięzcą w tej bitwie okazał się jedynie wielki książę litewski Witold Kiejstutowicz ${ }^{24}$. Również sam Jagiełło przestał być opatrywany mianem „zdrajcy narodu” ${ }^{25}$. Zwraca uwagę, że odwrotnie niż zdarzało się dotąd, nie pominięto unii horodelskiej (1413), mocą której potwierdzono partnerski charakter relacji Litwy z Koroną $(\ldots)^{26}$.

Nie oznacza to oczywiście braku jakichkolwiek błędów - najczęściej dotyczą one jednak podawania litewskiej formy nazwisk postaci, które badacz polski łączy ze swoją kulturą narodową. Łukaszewicz pisze na przykład o zamieszczonym w podręczniku obrazie Jana Matejki „Bitwa pod Grunwaldem", pod którym widnieje podpis: Dailininko Jano Mateikos. Nie rezygnuje przy okazji z zadania retorycznego pytania: „Rodzi się obawa, czy uczeń w tym wypadku nie uzna, że Mateika to artysta litewski?"27

Również wiedza dotycząca trudnych relacji polsko-litewskich na przełomie wieków XIX i XX w podręcznikach z 2015 roku oczyszczona została $\mathrm{z}$ naznaczeń negatywnych. $Z$ analiz pozycji Laikas. Istorijos vadovelis 9 klasei wynika, że ich miejsce zajęła forma ukazywania przeszłości z punktu widzenia przedstawicieli różnych narodów.

Esencję nowego spojrzenia na wspólną historię Polaków i Litwinów stanowi bardzo ciekawy diagram (...), gdzie zostały zestawione różne opcje postrzegania dziejów Wielkiego Księstwa Litewskiego (czym ono było?) przez różne narodowości (Litwinów, Białorusinów, Ukraińców, Rosjan, Żydów i Polaków) oraz taką ocenę ze strony współczesnych naukowców ${ }^{28}$.

Dla badań kwestii spuścizny kulturowej z czasów demokracji szlacheckiej szczególnie ważne wydaje się, że

${ }^{23}$ B. Łukaszewicz, UWAGI o litewskim podręczniku do nauki historii dla klasy jedenastej, s. 4, https://www.upc.smm.lt/ekspertavimas/vadoveliai/komisija/2015-metai/Istorijos-vadovelio-11-klasei-recenzija-lenku-kalba-2015.docx., [dostęp: 8.02.2019, godz. 15:58].

${ }^{24}$ Tamże, godz. 16:00.

25 Tamże, godz. 16:01.

${ }^{26}$ Tamże.

27 Tamże, godz. 16:04.

${ }^{28}$ A. Srebrakowski, Recenzja podręczników, wykonana na potrzeby posiedzenia PolskoLitewskiej Dwustronnej Komisji Ekspertów do badania problemów nauczania historii i geografii, Telsze, 10-13 maja 2016 r., s. 1. 
w części poświęconej ostatnim latom istnienia Rzeczypospolitej, (...) autorzy przedstawiają ją jako wspólne państwo polsko-litewskie, co do niedawna nie było na Litwie takie oczywiste, a w szeroko dostępnej literaturze niezbyt jeszcze powszechne ${ }^{29}$.

Sporo miejsca poświęcono także w podręczniku zagadnieniu Sejmu Czteroletniego, a Konstytucję 3 Maja nazwano „pierwszą spisaną litewską konstytucją" ${ }^{30}$. Sygnały te należy zinterpretować jako powolne reformowanie edukacji historycznej w kierunku przywracania Rzeczypospolitej Obojga Narodów do świadomości litewskiej. Nie powinniśmy jednak bezpośrednio utożsamiać tych przemian z dążeniem w kierunku likwidacji uczucia obcości wobec Polaków - wystarczy pamiętać choćby o zrównaniu przez władze litewskie w 2018 roku poziomu egzaminów maturalnych z języka litewskiego dla uczniów szkół polskich i litewskich. Poza argumentacją poświadczającą przydatność zmian dla kolejnych etapów kształcenia, istnieje także szereg wątpliwości, które budzą niepokój Polonii na Litwie.

Edukacja historyczna jest tylko jednym z obszarów napiętnowanych stereotypem niekorzystnego wpływu Polski na kształtowanie się kultury litewskiej. Badając odnoszenie się do tej kwestii historiografii litewskiej w XX wieku, Miknys pisze o niemal całkowitym wykluczeniu tematyki relacji obu narodów z obszaru badań, na co silny wpływ miały lata rządów komunistycznych i idei marksistowskich. Również po roku 1990

najważniejszą tendencją $\mathrm{w}$ historiografii litewskiej było badanie $\mathrm{i}$ interpretowanie przeszłości z perspektywy dziejów kształtowania się nowoczesnego narodu i państwa litewskiego oraz społeczeństwa obywatelskiego ${ }^{31}$.

Wnioski wynikające z analiz Miknysa wyjaśniają tendencyjność przytaczanych zapisów z podręcznika Historia Litwy od czasów najdawniejszych do unii lubelskiej, w których XX-wieczna niechęć do Polaków rzutowała na obraz czasów dawnych. Powtórzmy za wspomnianym historykiem:

(...) od 1989 roku w społeczeństwie litewskim można zauważyć wielkie zainteresowanie sprawami stosunków litewsko-polskich w pierwszej połowie XX wieku, lecz przede wszystkim na poziomie dziennikarskim i publicystycznym. Często są powtarzane $\mathrm{w}$ nieskończoność propagandowe stereotypy z okresu międzywojennego, a nawet sowieckiego. Wymienię tylko kilka dla przykładu: okupacja polska Wilna i Wileńszczyzny w latach 1920-1939, legiony Żeligowskiego czy rozpowszechniona teza, że Warszawa była zdecydowanym wrogiem niepodległości Litwy. Do tego do-

${ }^{29}$ Tamże, s. 2.

30 Tamże, s. 3.

31 R. Miknys, Litwini wobec Polski i Polaków: Spojrzenie na podstawie badań nad historia Polski w XX wieku w historiografii litewskiej ostatniego dwudziestolecia, Lublin 2012, s. 3. Autor stwierdza, że „historia przez długi czas była narzędziem służącym zachowaniu i rozwijaniu litewskiej tożsamości narodowej oraz państwowej". 
dać należy twierdzenie, iż świadomym celem polityki zagranicznej wskrzeszonego państwa polskiego było odbudowanie Rzeczypospolitej w jej granicach historycznych $\mathrm{z}$ roku $1772(\ldots)^{32}$.

Po wybiórczym nakreśleniu realiów, które przyczyniły się do obecnego braku akceptacji dla wspólnego dziedzictwa historycznego, warto zaznaczyć, że nadal istnieją spoiwa kulturowe ${ }^{33}$, mogące łagodzić oddziaływanie negatywnych stereotypów na wzajemne relacje. Pod pojęciem spoiw kulturowych rozumiem w pierwszej kolejności postacie, ale także wydarzenia, doceniane zarówno przez współczesnych Polaków, jak i Litwinów, ze względu na ich obecność i wpływ na dzieje tych narodów. Wielcy przodkowie - osoby darzone sympatią i szacunkiem, stale obecne w pamięci kulturowej, stanowią doskonały punkt wyjścia dla procesów ponownego „docierania się" społeczeństw, na których bieg wydarzeń wymuszał do niedawna minimalizowanie wzajemnych powiązań. Mowa tu przede wszystkim o tak zwanych bohaterach narodowych, choć w przypadku badań autorki niniejszego artykułu - mających na celu kulturową rehabilitację narodu szlacheckiego I Rzeczypospolitej - pojęcie to jest nieadekwatne. Z całą pewnością człowiekiem z minionej epoki, mogącym zespolić pamięć polską i litewską względem ostatnich lat istnienia wspólnego państwa, jest książę Michał Kleofas Ogiński.

Reprezentując najbardziej uświadomiony stan społeczny, o silnie rozwiniętym poczuciu tożsamości narodowej (obywatelskiej), Ogiński pretenduje do miana spoiwa kulturowego. Fakt akceptowania go jako postaci pozytywnej przez liczne narody, wywodzące się z I Rzeczypospolitej, otwiera drogę do przeanalizowania poglądów tego człowieka na kwestię wspólnoty z jednej strony, z drugiej zaś - do zastanowienia się nad słusznością nadania mu rangi naszego wspólnego bohatera.

\section{Bohaterowie w służbie rehabilitacji kulturowej}

Zgodnie z najstarszymi, antycznymi wzorcami bohater był konkurentem bóstwa, by następnie w toku dziejowych metamorfoz stawać się „nośnikiem

${ }^{32}$ Tamże, s. 4. Pojęcia „okupacja polska Wilna i Wileńszczyzny w latach 1920-1939, legiony Żeligowskiego" - przytacza autor jako cytat za: I. Šimelionis, Vilnija šimtmečio verpetuose, Vilnius 2002, s. 39-99; "Literatūrairmenas”, 08.04.1989, nr 15, s. 3; Ant sutarties stalo stovéjo kryžius. L. Želigovskio agresija turi būti įvertinta, "Voruta”, 18-24.02.1993, nr 7, s. 2. Pogląd mówiący, że „Warszawa była zdecydowanym wrogiem niepodległości Litwy” - przytacza autor jako cytat za: L. Truska, Antanas Smetona ir jo laikai, Vilnius 1996, s. 344.

${ }^{33}$ Podobne ujęcia kwestii obszarów wspólnych w pamięci kulturowej występują m.in. pod nazwami "punktów stycznych" oraz „węzłów pamięci” w pracach: M. Šapoka, Wielkie Księstwo Litewskie: próba nowego spojrzenia na punkty styczne polskiej i litewskiej pamięci historycznej, Projekt: Historia a teraźniejszość. Dziedzictwo Rzeczpospolitej Obojga Narodów a aktualne stosunki polskolitewskie, Lublin 2012; H. Łaszkiewicz, Pamięć i zapomnienie. Węzty pamięci w stosunkach polskolitewskich, Lublin 2012. 
porządku społecznego"34 i wreszcie "osiągnąć apogeum w zmienionym kontekście jako bohater romantyczno-narodowej śmierci «za ojczyznę»" ${ }^{35}$. Sprecyzujmy jednak pojęcie „bohatera” w takiej formie, aby uwzględniało sposób jego odbioru przez społeczności XXI wieku ${ }^{36}$. W tym kontekście decydującą rolę odgrywa dystans czasowy pomiędzy przedstawicielami kultury poznającej a potencjalnym bohaterem. Czas bywa utrudnieniem bardziej odbiorczym niż badawczym. Odbiorca przekazu, nie zajmujący się zawodowo badaniami historycznymi, przejawia niejednokrotnie niechęć wobec okresów bardzo odległych. Przyczyną nastawienia zachowawczego względem dziejów jest, według Szpocińskiego, „mierzenie oddalenia wydarzeń od teraźniejszości za pomocą czasu fizykalnego i wynikające z tego kryterium odróżniania historii najnowszej od dawnej" ${ }^{\prime 37}$. Dla każdego społeczeństwa istnieje wyraźna granica, poza którą znajduje się przeszłość już nieistotna (historia dawna). Nieistotność ta wyrasta z założenia, że z bardzo odległą przeszłością dany podmiot nie ma nic wspólnego, ponieważ tworzące ją wydarzenia w żaden sposób nie wpłynęły na jego rzeczywistość. Dla współczesnych Polaków okresem granicznym, spoza którego nie czerpiemy wzorców, ani podmiotów kultu bohaterstwa, jest wiek XIX. Traci na tym nie tylko pamięć monumentalna ${ }^{38}$ narodu, ale także zasób wzajemnych odniesień w relacji polsko-litewskiej.

Ze względu na dystans czasowy spotykamy dwa główne rodzaje bohaterów w odbiorze społecznym. Do pierwszego należy zakwalifikować ludzi, którzy żyli w czasach tak odległych, że pełne zrozumienie realiów ich funkcjonowania oraz motywów podejmowanych przez nich decyzji jest bardzo trudne. W związku z tym pozostają dalecy oraz nieuchwytni w odbiorze emocjonalnym. Ze względu na odmienność problemów aktualnych od dawnych, często wydają się niepotrzebni w procesie zacieśniania relacji społecznych. Grupę tę nazwałam bohaterami legendarnymi, a za przykłady posłużyć mogą postacie Mieszka I, św. Stanisława biskupa, czy Zawiszy Czarnego.

W pamięci historycznej, mniej więcej od momentu rozbiorów Rzeczypospolitej, pojawia się druga grupa bohaterów. Są to ludzie, którzy w naszym rozumieniu walczyli o sprawę narodową, nazwani przeze mnie bohaterami faktycznymi. Bohater faktyczny podejmuje działania, których motyw jest

${ }^{34}$ P. Czapliński, S. Obirek, Bohater, [w:] Modi memorandi. Leksykon kultury pamięci, red. M. Saryusz-Wolska, R. Traba, Warszawa 2014, s. 174.

${ }^{35}$ Tamże, s. 175.

${ }^{36}$ Część artykułu dotycząca współczesnego rozumienia pojęcia „bohater” opiera się na wybranych fragmentach zapisu roboczego mojego autorstwa, który wykorzystałam dla potrzeb pracy dyplomowej: My, studzy Maryi - muzyczny autoportret narodowy w pieśniach konfederatów barskich z roku 2017.

37 A. Szpociński, Formy przeszłości a komunikacja społeczna, [w:] A. Szpociński, P.T. Kwiatkowski, Przeszłość jako przedmiot przekazu, tom I, Seria: Współczesne Społeczeństwo Polskie wobec Przeszłości, Warszawa 2006, s. 13.

38 A. Szpociński, Przeszłość a środki przekazu, [w:] Tamże, s. 30-34. 
zrozumiały dla Polaka w XXI wieku, niezależnie od jego wiedzy historycznej. Jest więc stosunkowo bliski, jego życie często dokumentują źródła niewiele różniące się od nam współczesnych sposobów uwieczniania zdarzeń, przemawia w języku zrozumiałym, stawia sobie cele, którym łatwo możemy przypisać charakter patriotyczny. Czyny bohaterskie dokonywane są z myślą o całym narodzie, bez podziałów stanowych. Wspomnijmy tu Emilię Plater, Hipolita Cegielskiego, czy gen. Władysława Andersa.

Podział bohaterów zależny od dystansu czasowego jest stosunkowo prosty do rozgraniczenia. Większe trudności sprawia druga kategoria, którą również musimy brać pod uwagę przed zakwalifikowaniem Michała Kleofasa Ogińskiego. O randze bohatera decyduje także uznanie społeczne. Nawet faktyczni bohaterowie narodowi bywają poddawani segregacji przez pewne grupy społeczne, które podważają sensowność ich czynów. Dyskusja medialna przyczynia się do utrwalania rozbieżności poglądów społeczeństwa. W ten sposób zaistniała grupa bohaterów wątpliwych, którzy podlegają krytycznej ocenie, nie tylko ze strony specjalistów. Część z nich przy osądach kieruje się uprzedzeniami natury politycznej, inni ulegają presji współczesnej wizji bohaterstwa. Zgodnie z tą wizją bohater powinien odnosić zwycięstwo, a miarą wielkości jego czynu jest wąsko pojęty sukces. Bohaterowie zwycięstwa i sukcesu zostali stworzeni głównie przez działalność medialną po roku 1989 i szybko zyskali uznanie szerokich kręgów ludności. Postacie uznawane powszechnie nazwałam bohaterami uniwersalnymi. W porównaniu z nimi, bohaterowie wątpliwi reprezentują inny od współczesnego typ bohaterstwa, wpasowujący się w model romantyczny, poddawany obecnie silnej negacji. Bohaterstwo cnót i honoru, poświęcenia, czy powstańczego mesjanizmu zostało zdecydowanie wykluczone przez współczesny sposób postrzegania spoiwa kulturowego.

Działania Michała Kleofasa Ogińskiego przypadają na przełom wieków XVIII i XIX, jednak śmierć w 1833 roku sprawia, że trudno zakwalifikować go do epoki romantyzmu, przez pryzmat której postrzega się zazwyczaj bohaterstwo tamtego okresu. Reprezentując grupę magnacką, wraz ze wszystkimi jej cechami charakterystycznymi, książę plasuje się zdecydowanie w kręgu bohaterów legendarnych i dopiero dogłębna analiza stanu jego świadomości narodowej pomoże stworzyć nowy kontekst odbioru współczesnego. Ze względu na ewentualne uznanie społeczne podejrzewam początkowe przypisanie tej postaci bohaterstwa wątpliwego, ponieważ jej starania nie przyniosły ostatecznie pożądanego skutku: Rzeczpospolita upadła i nie udało się jej odbudować w granicach przedrozbiorowych. Ogiński nie został zwycięzcą, nie mógłby więc zasłużyć na powszechne uznanie jako bohater uniwersalny w XXI wieku.

Tymczasem, na Litwie przez znaczną część społeczeństwa postrzegany jest jako bohater narodowy - a więc uniwersalny i faktyczny - co poświadcza o ciągłych staraniach państwa, ukierunkowanych na docenianie tej postaci 
pomimo poniesionej porażki. Powtórzmy za Julkowską, że „trwała obecność bohatera w pamięci społecznej jest zależna (...) przede wszystkim od świadomego uruchomienia przez tę społeczność procesu pamiętania" ${ }^{39}$. Mamy zatem wyraźny sygnał, że zaistnienie Ogińskiego w polskiej pamięci historycznej oznaczałoby pojawienie się spoiwa kulturowego między Polakami a Litwinami. Zauważalnym dowodem autentycznej obecności postaci w litewskiej (oraz białoruskiej) kulturze były uroczystości, do których doszło z okazji 250. rocznicy urodzin księcia. Rok 2015 został oficjalnie ustanowiony przez sejm Litwy rokiem jego imienia. W celu upamiętnienia obchodów, wyemitowano okolicznościowe monety i znaczki pocztowe. 18 stycznia koncertem fortepianowym w wileńskim ratuszu zapoczątkowano cykl wydarzeń kulturalnych. W Pałacu Władców (Zamku Wielkich Książąt Litewskich) w Wilnie odbył się koncert kompozycji Ogińskiego. Jego utwory wykonała pianistka Mūzy Rubackytė, przy akompaniamencie Litewskiej Orkiestry Kameralnej ${ }^{40}$.

Najważniejsze wydarzenia miały miejsce na Żmudzi. Po odrestaurowaniu, dwa lata wcześniej, neorenesansowego pałacu Ogińskich w Płungianach, odbyła się w nim konferencja naukowa, następnie już po raz dziesiąty zorganizowano Międzynarodowy Festiwal im. Michała Kleofasa Ogińskiego. Przez cały wrzesień litewskie orkiestry symfoniczne, kameralne oraz zespoły chóralne dawały koncerty muzyki klasycznej. Poza tym odbyły się pokazy wyścigów konnych, prezentacja kalendarzy z XIX i XX wieku, a także wystawa czterdziestu rzeźb polskiego artysty, urodzonego i wychowanego w Wilnie, Stefana Wierzbickiego. 26 września występ Państwowej Akademickiej Orkiestry Symfonicznej Białorusi uroczyście zakończył to wydarzenie ${ }^{41}$.

W żmudzkim Retowie zorganizowano międzynarodowy konkurs młodych wykonawców pod hasłem: „Perły twórczości Michała Kleofasa Ogińskiego". Jednym z ostatnich wydarzeń obchodów było odsłonięcie w tej miejscowości pomnika poświęconego bohaterowi. Dyrektor Muzeum Historii Kultury Ogińskich Vytas Rutkauskas omówił go jako „dzieło koncepcyjne nawiązujące do herbu rodu Ogińskich, przypominające kwiat wykonany z bordowego granitu osadzony na czarnym cokole" ${ }^{\prime 2}$, zaś mer rejonu retowskiego Antanas Černeckis dodał: „W tym pomniku będzie zawarte podziękowanie dla wszystkich Ogińskich, kiedykolwiek mieszkających czy

${ }^{39}$ V. Julkowska, O roli historii i pamięci w kreowaniu bohaterów przeszłości. Wprowadzenie, [w:] Jan Kiliński. Historia i pamięć, red. V. Julkowska, Poznań - Trzemeszno 2015, s. 9.

${ }^{40} \mathrm{http}: / / 124.1 \mathrm{t} / \mathrm{pl} /$ kultura-pl/item/51052-w-wilenskim-ratuszu-inauguracja-rokumichala-kleofasa-oginskiego, [dostęp: 11.02.2019, godz. 16:03].

${ }^{41}$ https:/ / dzieje.pl/ kultura-i-sztuka/litwa-rozpoczal-sie-miedzynarodowy-festiwal-im-michala-oginskiego, [dostęp: 11.02.2019, godz. 15:00].

${ }^{42}$ Cytat z wypowiedzi udzielonej Radiu „Znad Wilii”, http://zw.lt/kultura-historia/ odsloniecie-pomnika-rodu-oginskich-w-retowie/ , [dostęp: 11.02.2019, godz. 15:11]. 
goszczących w Retowie. Za ich zasługi, za ich wielkie dzieła będzie to pomnik dla całego rodu" ${ }^{43}$.

Ogiński urodził się w Guzowie 25 IX 1765 roku, jako drugie dziecko Andrzeja Ignacego Ogińskiego i Pauli Anny Barbary z Szembeków Ogińskiej. $\mathrm{W}$ roku $1788^{44}$ przyjął obowiązek posła $\mathrm{z}$ województwa trockiego; $\mathrm{w}$ tym czasie otrzymał od Stanisława Augusta Order Świętego Stanisława, a później Order Orła Białego. Od 1789 roku pełnił funkcję dyplomaty w służbie króla polskiego, przez którego został skierowany jako poseł nadzwyczajny na pierwszą misję do Hagi (1790-1791). Od samego początku cieszył się uznaniem polityków międzynarodowych, głównie dzięki postaci kuzyna swego ojca - hetmana wielkiego litewskiego Michała Kazimierza Ogińskiego. W czasie uchwalania Konstytucji 3 Maja Michał Kleofas przebywał w Warszawie, przyjmując wobec tego dokumentu postawę umiarkowanie przychylną uważał bowiem, że obiecująca inicjatywa została podjęta o kilka lat za późno. Odziedziczenie majątków na terenach dzisiejszej Białorusi wymogło na nim złożenie przysięgi na wierność carycy Katarzynie II, do czego prawdopodobnie doszło po wcześniejszym uzgodnieniu z królem Rzeczypospolitej ${ }^{45}$. Niemniej pozostał nadal wierny sprawie polsko-litewskiej. W czasie trwania sejmu grodzieńskiego z 1793 roku, już jako wielki podskarbi litewski podjął próbę wycofania się z obrad, na które powrócił pod przymusem Rosji. Nie mogąc pogodzić się z decyzjami zapadłymi na sejmie, wziął aktywny udział w insurekcji kościuszkowskiej, organizując akcje odwetowe w okresie oblężenia Wilna. Po upadku powstania udał się jako agent polski do Konstantynopola i Paryża. Prawdopodobnie to w tym okresie (1794) skomponował swój najbardziej znany utwór, polonez „Pożegnanie Ojczyzny”, a niektórzy badacze dopuszczają pewne prawdopodobieństwo, że w 1797 roku we współpracy z Wybickim, na prośbę Dąbrowskiego, stworzył „Pieśń Legionów”, będącą obecnym hymnem naszego kraju ${ }^{46}$. Kontakty z Napoleonem Bonaparte ostudziły jego nadzieje, pokładane we Francji. Zarówno spotkania osobiste, jak i dialog korespondencyjny przekonały Ogińskiego, że wielki wódz nie zmierza do przywrócenia Rzeczypospolitej. Tymczasem w 1802 roku Aleksander I wyraził zgodę na jego powrót z przymusowej emigracji. Osiadłszy w odziedziczonym po Franciszku Ksawerym Ogińskim Zalesiu, postanowił wpłynąć

43 Tamże.

44 W 1786 r. również brał udział w obradach, jednak wyłącznie z konieczności zastąpienia swego ojca.

${ }^{45}$ W swojej pracy: Michat Kleofas Ogiński. Życie, działalność i twórczość, Londyn 2003, potomek Ogińskiego - Andrzej Załuski zaznacza, że nie istnieją żadne zapisy potwierdzające, iż do takiego złożenia przysięgi doszło. Prawdopodobnie jednak musiało to mieć miejsce ze względu na obowiązujące prawo.

${ }^{46}$ Kwestia ta pozostaje dyskusyjna, choć w XIX w. uznawano współautorstwo Ogińskiego jako pewnik. Patrz: tamże, s. 65 i n., 105 i n. 
na decyzje cara względem terytoriów polskich i litewskich. Jeszcze w czasie trwania wojen napoleońskich odbył z nim szereg spotkań, zachęcając do odtworzenia państwa w granicach sprzed 1772 roku i przyjęcia tytułu króla, bez likwidacji systemu demokratycznego. Aleksander przyjął te propozycje bardzo życzliwie; w 1810 roku zaproponował magnatowi przyjęcie senatorstwa rosyjskiego, na co Ogiński przystał, by już w roku 1811 przedstawić swój projekt restytucji Wielkiego Księstwa Litewskiego. Car obiecywał swemu senatorowi realizację jego planów po pokonaniu Napoleona, dlatego postanowienia kongresu wiedeńskiego bardzo zawiodły Michała Kleofasa. W kolejnych latach występował z licznymi petycjami w sprawie sytuacji szlachty litewskiej, stopniowo jednak jego relacja z Aleksandrem uległa ochłodzeniu. Pod wpływem utraty znaczenia na dworze carskim, postanowił wycofać się z życia politycznego i w 1822 roku osiadł na stałe we Florencji. Tam przystąpił do pisania Pamiętników o Polsce i Polakach, w których wyłożył szczegółowo wszystkie swoje dążenia począwszy od roku 1788, aż do 1815. Zostały one następnie wydane po raz pierwszy przez jego byłego osobistego sekretarza Leonarda Chodźkę w Paryżu w 1827 roku, w języku francuskim (w którym zostały napisane). Pamiętniki są zaledwie pierwszą, lecz jedyną opublikowaną częścią wspomnień księcia, który kontynuował opis wydarzeń aż do roku 1830. Poza tym nie zawierają pewnej części tekstu, na upowszechnienie której przed swoją śmiercią Ogiński nie wyraził zgody ${ }^{47}$. Mają natomiast tę wielką zaletę, że autor pragnął poprzez ich treść przekazać potomnym wszystkie najcenniejsze w jego odczuciu wątki, głównie zaś pozostawić myśl patriotyczną i pamięć po utraconym państwie. Zmarł w 1833 roku.

W kontekście niezgodności w polskiej i litewskiej wizji tego okresu oraz dominującego stereotypu odwiecznej sprzeczności interesów obu narodów, pragnę poświęcić tę część artykułu wybranym fragmentom Pamiętników o Polsce i Polakach, w których sam Ogiński wypowiadał się o rozbiorach, jako o nieszczęściu wszystkich bez wyjątku, dając dowód silnego poczucia wspólnoty. Wielkie poświęcenie z jego strony, liczne próby ratowania wspólnej ojczyzny, a zwłaszcza silne zespolenie w tej postaci tożsamości Polaka i Litwina, stają się motywacją do zgłębienia magnackiego sposobu postrzegania sprawy niezależności obu narodów. Podobnie jak przedstawiciele narodu szlacheckiego z końca XVIII wieku stali się na wiele lat przyczynkiem do podkreślania i tłumaczenia naszej wzajemnej obcości (zwłaszcza w historiografii i edukacji historycznej na Litwie), obecnie Michał Kleofas Ogiński daje powody do zmiany takiego dyskursu i zapoczątkowania kształtowania koncepcji wspólnego bohatera.

${ }^{47}$ Materiały te znajdują się w Rosyjskim Państwowym Archiwum Akt Dawnych w Moskwie; są to: Additions a mes memoires oraz Observations sur les evenements arrives en Pologne depuis la fin de novembre 1830. 
Najbardziej burzliwym okresem, który stwarzał możliwość zerwania poczucia więzi obywatelskiej między szlachtą polską i litewską, był czas walk wojsk koalicji antyfrancuskiej z Wielką Armią oraz pertraktacji na arenie międzynarodowej w kwestii przyszłego podziału Europy. Ograniczę się zatem do tego okresu także w zapisie Ogińskiego, analizując kontekst rzekomej oddzielności Litwinów od Polaków, jak również sposób postrzegania kwestii wspólnej sprawy przez autora.

\section{Zrozumieć, przyjąć, przekazać - Pamiętniki o Polsce i Polakach}

Pod koniec sierpnia 1812 roku Ogiński wręczył dyplomacie francuskiemu w Wilnie sporządzony przez siebie zapis, w którym podjął próbę udzielenia odpowiedzi na prowokacyjne pytanie Francji, zgodnie z zapisem autora brzmiące:

Czemu Napoleon znalazł mieszkańców tej prowincyi [Litwy - przyp. M.G.] daleko mniej ufającymi, zimniejszymi i wiele mniej skwapliwymi do gromadzenia się około swych sztandarów, aniżeli Polaków zamieszkujących księztwo Warszawskie? ${ }^{48}$

Magnat rozpoczął od szczegółowego wyłożenia historii współpracy polsko-litewskiej, a następnie początków istnienia państwa litewskiego. Wyraźnie starał się uświadomić Francuzom, że mimo oddzielności regionalnej, obu grupom należy się miano jednego narodu, a doszukiwanie się różnic w tym kontekście z założenia jest błędne. W przypisie zamieszczonym w Pamiętnikach pod tekstem dokumentu sam podsumował z niemałą satysfakcją, iż jego pismo

wywarło silne wrażenie na wszystkich Francuzach, którzy je poznali. Zamknęło także usta wszystkim tym, co uważali Litwinów jako Polaków wyrodnych, którzy ich oskarżali, że stracili wszelkie uczucie dla ojczyzny i którzy im wyrzucali, że trzymają z Moskwą i że są oddani Cesarzowi Alexandrowi do tego stopnia, że wyrzekają się przywrócenia Polski przez Napoleona ${ }^{49}$.

Pragnąc wyjaśnić ową specyficzną jedność, współwystępującą z oddzielnością, pisał:

(...) mam zamiar objaśnić tych, co nie znają Litwy lepiej od antypodów, i co mówią o Litwinach jako o narodzie różniącym się całkiem od Polaków właściwych, dając im pewne wiadomości o tym kraju i o kraju mieszkańcach.

${ }^{48}$ M.K. Ogiński, Pamiętniki o Polsce i Polakach od r. 1788 aż do końca r. 1815, tom III, Dodatek do księgi X, Poznań 1870, s. 181.

${ }_{49}$ Tamże, s. 181-198. 
Nie ma bez wątpienia wyraźnej różnicy między Polakami a Litwinami, szczególnie w klasie szlacheckiej, która sama, jeźli tak wolno powiedzieć, stanowi ciało narodu, lecz nie należy przypuszczać, że to dopiero od czasu połączenia obu tych krajów należy datować sławę, jaką Litwini pozyskali sobie w historyi krajów północnych i imię, którego im nigdy nie zaprzeczono, dzielność przedsiębiorczości i miłości kraju $(\ldots)^{50}$.

Główny wątek dotyczył faktu zachowania przez szlachtę litewską jej odrębności, która nigdy nie została tej grupie odebrana, i której świadomość istniała także w 1812 roku. Zarazem owa odrębność nie mogła być, według Ogińskiego, postrzegana jako wykluczająca Litwinów z szerszej grupy „Polaków”, czyli spadkobierców Rzeczypospolitej Obojga Narodów. Choć

po złączeniu Litwy z Polską pokazali się Litwini zazdrosnymi o zachowanie dawnych swych praw i przywilejów, (...) znajdowano ich zawsze skłonnymi do wszystkich ofiar, jakich wymagano od nich, gdy chodziło o dobro ogólne Ojczyzny ${ }^{51}$.

Piszący pragnął przekazać i utrwalić wzorzec, zgodnie z którym dobro wspólne było najważniejsze dla członków narodu szlacheckiego, a dążenia do pogłębiania różnic, wynikających z pochodzenia, nigdy nie zdominowały tego środowiska. Nie oznaczało to definitywnego wykluczenia jakichkolwiek niezgodności, ale udowadniało, że nie należy przypisywać im roli czynnika osłabiającego naród od wewnątrz. Autor przywołuje obrady Sejmu Wielkiego jako przykład dążeń do zjednoczenia, kiedy to Litwini

nabyli pewności, że dla wspólnego interesu i aby dać więcej trwałości nowej formie rządu (...) jest rzeczą potrzebną ścieśnić więcej stosunki między Litwą a koroną, aby z tych trzech ${ }^{52}$ prowincyi utworzyć tylko jedno silne państwo i znieść zupełnie różnice, które istniały dotychczas między Polakami a Litwinami $(\ldots)^{53}$.

Wykładając taki model postrzegania sprawy polsko-litewskiej, Ogiński przedstawiał podejście byłego Wielkiego Księstwa Litewskiego przez pryzmat swoich pragnień. W przytaczanych cytatach powinniśmy dopatrywać się przede wszystkim uzewnętrznienia jego własnych poglądów, zgodnie z którymi „poświęcenie dla Ojczyzny było uważane za obowiązek równie słodki, jak święty do wypełnienia" ${ }^{44}$. Poza tym, tożsamość społeczności regionalnych współistniała z akceptacją całego społeczeństwa, dla którego umownie używano w omawianych czasach przymiotnika „polskie”. Wydaje się, że mamy tu do czynienia z bardzo dojrzałym patriotyzmem jednostki, wy-

${ }^{50}$ Tamże.

51 Tamże, s. 181-189.

${ }^{52}$ Mowa o dwóch polskich prowincjach: Wielkopolsce i Małopolsce, występujących tu pod jedną nazwą "korony”.

${ }_{53}$ M.K. Ogiński, Pamiętniki o Polsce i Polakach, s. 181-198.

${ }^{54}$ Tamże, s. 181-189. 
kraczającej poza granice interesu prywatnego czy stanowego i akceptującej konieczność poświęcenia się dla dobra wspólnego. Przez cały czas trwania konfliktu na terenach byłej Rzeczypospolitej zmartwieniem Ogińskiego, na równi z sytuacją ziem litewskich, pozostawały wydarzenia w rdzennej Polsce. $\mathrm{W}$ tym samym dokumencie wyjaśnia:

Kilka wypadków następujących po tej epoce przyczyniło się do ochłodzenia jeszcze uwielbienia Litwinów dla Napoleona i utrzymywania ich nieufności. W początku kampanii r. 1809 ujrzeli księztwo Warszawskie pozostawione swym własnym siłom. Korpus małoliczny Polaków pod rozkazami księcia Józefa Poniatowskiego był przeznaczony na obronę kraju przeciw nieprzyjacielowi, kiedy większa część armii polskiej walczyła w Hiszpanii. Napoleon pozostawił na łaskę losu kraj, który mu dostarczył tyle zasobów, naród, który mu okazał tyle zaufania i poświęcenia! ${ }^{55}$

Na zakończenie deklaruje realne oczekiwania mieszkańców ziem litewskich, aby mogli uzyskać $\mathrm{z}$ „dawnych prowincyi polskich odzyskanych królestwo Polskie przywrócone" ${ }^{\prime 56}$. Jak wiemy, pojęcie prowincji nie zostało jeszcze na początku XIX wieku naznaczone pejoratywnie, natomiast sugerowało równość różnych części ojczyzny, służąc jedynie do ogólnego podziału terytorialnego. W ten sposób rosyjski senator wyjaśnił stronie francuskiej, że

Litwini nie ustępowali nigdy w niczem mieszkańcom innych prowincyi polskich i nie ma wątpliwości, że ten coby (...) się ogłosił królem polskim i wskrzesicielem ich ojczyzny, byłby pozyskał niezaprzeczone prawa do ich wdzięczności i mógł być pewien znaleźć w nich zaufanie, zapał, a nawet egzaltacyą ${ }^{57}$.

Starał się wyraźnie ukrócić dyskusję polityczną, w podtekście której przebijały wątki o wrogości Litwy względem Księstwa Warszawskiego. Jako były podskarbi wielki litewski niejednokrotnie dopominał się o nie podważanie polsko-litewskiego uczucia braterstwa. Było tak między innymi w 1812 roku, kiedy w pierwszym wydanym numerze dziennika rosyjskiego, zatytułowanego „Syn Ojczyzny”, znalazł „lichą piosenkę żołnierską, przepełnioną obraźliwemi wyrażeniami i wycieczkami przeciw Polakom, wraz z groźbami ukarania ich i pomszczenia się na nich w Warszawie" ${ }^{58}$. Reakcja była natychmiastowa i przybrała formę odważnej perswazji skierowanej wprost do Aleksandra: „Nie czekając sposobności, aby odwiedzić cesarza i mówić z nim w tym względzie, pochwyciłem natychmiast za pióro i napisałem na prędce do niego list" $(\ldots)^{59}$. W odpowiedzi car zaprosił Ogińskiego na obiad dwa

\footnotetext{
55 Tamże, s. 181-198.

${ }^{56}$ Tamże, s. 181-189.

57 Tamże.

58 Tamże, s. 165-167.

59 Tamże.
} 
dni później, wydając równocześnie rozkaz do redakcji żurnala, by tego typu zajście się nie powtórzyło. Spotkanie wyraźnie zapadło w pamięć obrońcy sprawy polskiej, potęgując jego nadzieje, pokładane w osobie imperatora:

Dzień 16 Listopada nie zatrze się nigdy w mej pamięci. (...) Ponieważ wszystko, co słyszałem z ust cesarza było najwyższej wagi pod wszelkiemi względami dla mnie, ponieważ odtąd mniej niż kiedykolwiek wątpiłem o jego zamiarach przywrócenia Polski $(\ldots)^{60}$.

Należy zaznaczyć, że Ogiński pragnął potwierdzać popularność swych oczekiwań, przytaczając w Pamiętnikach także treści przemówień innych panów litewskich. W tym celu udostępnił fragment ich dyskusji z urzędnikami francuskimi. Francuzi zarzucali swym rozmówcom, że z powodu przywiązania do Moskwy i pobudek egoistycznych, ludność Litwy nie wsparła należycie ich wojsk. Dla Ogińskiego wyjątkowo ważna okazała się następująca część odpowiedzi:

Mówicie o naszej niepodległości (...). (...) Wasi audytorowie, ludzie zupełnie nowi $\mathrm{z}$ administracyą całkiem nową, zarządzają naszemi prowincyami. (...) Pokazują nam wszędzie cesarza, a nigdzie jeszcze Rzeczypospolitej. (...) Wilno mimo naszych próśb pozostaje oddzielone od Warszawy; żądacie od nas, rozdzielonych, tej ufności do naszych sił, które jedność tylko może nadaćc1.

Nie była zatem Rzeczpospolita dla magnaterii wywodzącej się z "prowincji" litewskiej formą bolesnego ucisku; istniały środowiska podzielające oczekiwania Michała Kleofasa, wtórujące jego idei silnego zjednoczenia dla jednakowego dobra wszystkich. Takiej konwencji przyświecała idea jednego narodu szlacheckiego, potrafiącego zachować regionalną odrębność, ale od potencjalnych sprzymierzeńców z Europy zachodniej oczekującego wyłącznie scalenia swego dawnego państwa. Trudno jest kwalifikować Ogińskiego wyłącznie jako bohatera współczesnych Białorusinów (ze względu na terytoria, z których wywodził się jego ojciec i na których ród posiadał znaczny majątek) lub Litwinów (ze względu na reprezentowanie spraw szlachty litewskiej w czasach porozbiorowych), skoro sam podmiot podkreślał stale, że tożsamość z pochodzenia oraz tożsamość z posiadania nie są opozycyjne wobec szerzej pojętej tożsamości narodowej, zwanej w XVIII i XIX wieku „polską". Wprowadzam pojęcia tożsamości z pochodzenia i posiadania, jako pomniejsze formy, nie tyle istniejące obok tożsamości narodu politycznego, lecz stanowiące jej integralną część. Jeszcze wyraźniej omawiany bohater ukazał to w swojej postawie wobec Aleksandra I, proponując

${ }^{60}$ Tamże.

${ }^{61}$ Tamże, s. 202; Ogiński cytuje za: Wyciag z historyi Napoleona i wielkiej armii przez p. generata hr. de Segur, tom I s. 150-157. Szóste wydanie. 
mu nieustannie utrzymanie kierunku „polskiego” w dokumentach układanych na zlecenie cara, i następnie przekazywanych mu do zaakceptowania. Było tak na przykład z „Projektem listu, jaki jego Cesarska Mość ma wyprawić do księcia marszałka Kutuzowa przedłożonym według jego rozkazów, a dołączonym do (...) listu z 7 października 1812". W imieniu Aleksandra Ogiński napisał w nim:

Jest ci rzeczą znaną, Panie marszałku, (...) że ułożyłem oddawna projekt przywrócenia królestwa polskiego w zamiarze zyskania przez to rzeczywistego pomnożenia sił cesarstwa, (...) i dopełnienia życzeń 12 milionów mieszkańców, którzy pragną przywrócenia swej Ojczyzny a którzy będą połączeni z Rossyą węzłami nierozerwanemi. (...) Posuwając się w ten kraj poniesiesz na brzegi Wisły zapewnienie mego szacunku i mej życzliwości dla narodu polskiego. Powiedz Polakom, że oceniałem zawsze ich waleczność, ich miłość i wierność dla Ojczyzny i monarchy. Powiedz im, że mam postanowienie przywrócenia królestwa polskiego i ogłoszenia się jego królem, skoro wojska me wypędzą zeń nieprzyjaciela. Powiedz im, że połączeni z Rossyą w mojej i mych następców osobie, zachowają wiarę swych ojców, osobny zarząd i prawa narodowe oparte na konstytucyi 3 Maja 1791, która im zawsze była tak drogą. (...) Połączyć pod sztandarem narodowym 12 milionów ludzi wzdychających za przywróceniem ojczyzny, nadać im powtórnie istnienie polityczne utracone od 16 lat, połączyć nierozerwanemi węzłami braterstwa i wzajemnej obrony dwa waleczne narody sławiące się z tegoż samego pochodzenia, takie to powinny być szlachetne rezultaty Twoich zwycięztw w kraju, którego istnienie jest koniecznem dla naszej chwały i dobra państwa ${ }^{62}$.

Zauważmy, iż w obrazie społeczeństwa byłej Rzeczypospolitej Obojga Narodów pragnienie jej przywrócenia przypisywane jest wszystkim mieszkańcom tego państwa, niezależnie od przynależności stanowej (stąd liczba 12 milionów). Ma to wymiar propagandowy, świadcząc o doniosłości carskiego przedsięwzięcia, ale zdradza również wyraźną tendencję w postrzeganiu przez Ogińskiego członków dawnego unijnego tworu. W sytuacji, która zaistniała na początku XIX wieku, walka o interes stanowy stopniowo ustępowała miejsca staraniom o dobro ogółu ludności. Litewski magnat nie zapomniał w swym tekście o podzieleniu się ideą braterstwa z Rosjanami, wymieniając ich jako jeden z dwóch „walecznych narodów sławiących się z tegoż samego pochodzenia”. Drugą stroną układu miał być naród wyczekujący "przywrócenia królestwa polskiego", czyli ci wszyscy, których etnogeneza czyniła Litwinami, Polakami z ziem dawnej Korony oraz Rusinami. Fundamentem istnienia tego drugiego narodu, oraz jego niezaprzeczalnej obecności w debacie publicznej omawianego okresu, była Konstytucja z 1791 roku - gwarancja przetrwania i dalszego rozwijania się nowoczesnej, ponadstanowej formy narodowej.

${ }^{62}$ M.K. Ogiński, Pamiętniki o Polsce i Polakach, s. 155. 
„Projekt proklamacyi do narodu polskiego przedłożony cesarzowi Alexandrowi według jego rozkazów" Ogiński rozpoczyna od zwrotu wykorzystującego powszechność nazwy „Polak”. Nie tylko nie ryzykuje urażenia żadnej z grup odbiorców, lecz przeciwnie - dąży tym sposobem do przekonania wszystkich o zbliżającej się możliwości zjednoczenia sił i przyjęcia wspólnego stanowiska względem Rosji:

Polacy! Będąc naczelnikiem narodu, który jak Wy winien swój początek walecznym Słowianom; (...) znajdując się na czele armii znanej z męztwa, z energii i z poświęcenia bohaterskiego; (...) czyniąc z polski najskuteczniejszą zasłonę cesarstwa, oświadczam w obliczu nieba i ziemi, że przywracam i restauruję królestwo polskie, łącząc pod tem nazwiskiem wszystkie województwa i ziemie polskie przyłączone do Rosyi w trzech podziałach następujących po sobie z r. 1773, 1793 i 1796 wraz z okręgami Białostockim i Tarnopolskim, z księztwem warszawskiem; Że powołując się na pomoc boską, kładę na mą głowę królewską koronę Polski osobną, co się tyczy prawa monarchicznej władzy, lecz połączoną w mej osobie z cesarstwem rosyjskiem; (...) Że uważam konstytucyą z 3 Maja 1791, co się tyczy organizacyi formy rządu i prawodawstwa, jako prawo podstawowe narodu polskiego i że zamierzam rządzić według jej zasad, panować nad Wami i pracować nad utrwaleniem Waszego szczęścia $(. . .)^{63}$.

Pozostaje jeszcze kwestia odnoszenia się Ogińskiego do zagadnienia jedności bądź rozdzielności szlachty polskiej i litewskiej jako narodu politycznego, bądź też dwóch niezależnych narodów politycznych. Dla tego etapu analizy konieczne jest przytoczenie tych zapisów z Pamiętników o Polsce i Polakach, które nie powstały na żądanie cara, ani na potrzeby misji dyplomatycznych, lecz ukazały prywatne przemyślenia autora. Pozostańmy nadal w dotychczasowym kręgu tematycznym i rozważmy powyższą sprawę $\mathrm{w}$ odniesieniu do nadziei, jakie pokładał on w osobie cara. Uważam ten kierunek analizy za konieczny przede wszystkim dlatego, że właśnie opowiedzenie się po stronie Rosji w czasie trwania wojen napoleońskich jest najczęstszym powodem wykluczania postaci z polskiej pamięci historycznej jako bohaterów. Współcześni odbiorcy akceptują uproszczony schemat „dobrego Napoleona” i „złego Aleksandra", zaś postawy prorosyjskie na każdym etapie naszych dziejów bywają postrzegane jako zdrada narodu. Niemniej jednak Ogiński, rozliczając po latach cara z doznanego przez siebie zawodu, nie naznaczył jego postaci jednoznacznie negatywnie, lecz podjął próbę retrospektywnego powrotu do swych uczuć z 1813 roku. Dominantą pozostała tęsknota za jednością Rzeczypospolitej:

Ośmielono się mieć nadzieję, że Cesarz przywróci Polskę (...). Pochlebiano sobie, że trwa w zamiarze przyłączenia do Księztwa Warszawskiego dawnych prowincyi polskich połączonych z Moskwą, aby utworzyć Królestwo Polskie, któreby miało króla

${ }^{63}$ Tamże, s. 161-162. 
i konstytucyę. Wiedziano, że (...) przemawiałem zawsze za sprawą mych ziomków; że miałem częste rozmowy z Cesarzem w przedmiocie przywrócenia Polski; że mi polecił wypracowanie ustawy dla ośmiu gubernii cesarstwa zamieszkałych przez Polaków w zamiarze uorganizowania ich i utworzenia z nich Księztwa czy królestwa Litewskiego (...). Było rzeczą wiadomą, że pracę tę uważano za przygotowawczą do zorganizowania, skoro okoliczności na to pozwolą, formy rządu Królestwa Polskiego. Miano więc wszelki powód spodziewać się, że (...) będę miał sposobność utrzymania Jego Cesarskiej Mości w jego dobrych zamiarach dla mych ziomków i przypomnieć mu obietnicę, do której przywięzywaliśmy tyle ceny ${ }^{64}$.

Choć w litewskiej pamięci historycznej funkcjonuje przekonanie, zgodnie z którym Ogiński przez cały okres swej działalności po rozbiorach dążył do odtworzenia wyłącznie Wielkiego Księstwa Litewskiego, z powyższego opisu wynika wyraźnie, iż traktował to jedynie jako etap na drodze do „przywrócenia Polski". Nie ma potrzeby przypisywania mu starań wybiórczo, aby uwidocznić silniej wyłączne prawo Litwinów do tego bohatera. Przemawianie „zawsze za sprawą swych ziomków” - czyli szlachty litewskiej oraz ludności zamieszkującej gubernie wschodnie - wynikało po prostu z położenia geopolitycznego, w jakim magnat znalazł się przez wzgląd na swe dobra, a także na pełnione wcześniej funkcje (np. wielkiego podskarbiego litewskiego). Nie wątpię, że będąc w tym czasie w Wielkopolsce, nie zaprzestałby działalności politycznej w kierunku przywrócenia kraju poprzez scalenie wszystkich jego byłych ziem. Ponadto, z przytoczonego fragmentu wnioskuję, iż rzekoma przyjaźn z Aleksandrem I wynikała z doskonale prowadzonej gry dyplomatycznej, podobnie jak w ostatnich latach XVIII wieku potrafił Ogiński odgrywać rolę zwolennika francuskiej idei wolności, równości i braterstwa, czemu dawał wyraz między innymi zwracając się do swych korespondentów per „Obywatelu!” ${ }^{65}$. Powyższe słowa mogą oczyścić tę postać z potencjalnych zarzutów zdrady sprawy polskiej, a sygnalizują raczej, że podjęte przez nią ryzyko było poświęcone ludziom po obu stronach frontu wojennego: zarówno mieszkańcom ziem litewskich, jak i Księstwa Warszawskiego.

Postanowienia kongresu wiedeńskiego, jakkolwiek silnie zawiodły księcia, nie osłabiły jego determinacji w działaniu. Dopiero siedem lat później pogodził się z nową sytuacją, w której jego osoba przestała się liczyć na dworze carskim. Pamiętniki pisał z perspektywy całego swego życia, ubolewając nad tym, czego był świadkiem. Podejmował jeszcze nieśmiałe próby usprawiedliwiania Aleksandra, w rzeczywistości zaś własnej porażki politycznej, jednak zdawał sobie sprawę z wartości straty, jaką poniosły miliony - nie zawsze tego świadome lub mające z czasem tę świadomość utracić.

${ }^{64}$ Tamże, s. 109.

${ }^{65}$ Patrz np. List Ogińskiego do Rymkiewicza z 6 grudnia 1796 r., [w:] W. Smoleński, Emigracya polska w latach: 1795-1797: (materyaty historyczne), Przegląd Historyczny, 1910, 11/3, s. 356. 
Tak to Polacy, którzy poczynali być dumnymi z opieki tak potężnego monarchy, jakim był cesarz Aleksander i którzy się sądzili raz jeszcze być bliskimi osiągnienia celu swych życzeń, widzieli się zmuszonymi wyrzec się nadziei być połączonymi pod jego berłem, co jedno tylko mogło osłodzić ich los i pocieszyć ich po stracie istnienia niepodległego, którego uzyskać już nie było w ich możności ${ }^{66}$.

W pamięci Ogińskiego organizm polityczny, mogący istnieć dzięki zjednoczeniu ziem oraz interesów polskich i litewskich, był formą wyjściową i warunkiem do postępowania procesu kształtowania się społeczeństwa o wspólnej tożsamości. Wydaje się, że przynajmniej od momentu inicjacji Konstytucji 3 Maja $^{67}$, magnat podświadomie oczekiwał jego kontynuacji. Uznanie wszystkich stanów za członków narodu było nierozerwalnie związane z łącznością wszystkich prowincji, a to wpłynęło na całokształt dążeń politycznych Michała Kleofasa. Choć wywodził się ze szlachty litewskiej, pozostał wierny przynależności do wieloetnicznego tworu Rzeczypospolitej Obojga Narodów.

\section{Zakończenie}

Podejmując próbę ukazania prapoczątków kształtowania się negatywnego stereotypu Polaka na Litwie oraz rzutowania tego stereotypu na postrzeganie przez Litwinów wspólnego okresu naszych dziejów, przytoczyłam fragmenty różnych tekstów, poczynając od schyłku XIX wieku aż po czasy współczesne. Następnie przyjęłam kierunek poszukiwania wspólnego bohatera obu narodów, wywodzącego się z czasów przedrozbiorowych, wolnych od późniejszych naznaczeń nacjonalistycznych. Posłużyłam się analizą fragmentów z Pamiętników o Polsce i Polakach Michała Kleofasa Ogińskiego. Przeprowadziłam ją na trzech płaszczyznach: postawy autora wobec polityki Francji, wobec polityki rosyjskiej (zapiski bezpośrednio z lat 1812-1815), oraz wobec kwestii tożsamości polsko-litewskiej (retrospekcja z lat 1824-1826). Praca ta miała uświadomić czytelnikowi, że podobnie jak współcześni Litwini i Białorusini, także Polacy mogą w wielkim polityku i kompozytorze postrzegać swojego bohatera, ponieważ reprezentował on interesy wszystkich mieszkańców utraconego, wspólnego państwa.

${ }^{66}$ M.K. Ogiński, Pamiętniki o Polsce i Polakach, s. 99.

${ }^{67}$ Artykuł II Konstytucji gwarantuje stanowi szlacheckiemu zachowanie wszelkich przywilejów, nadanych dotąd przez władców z dynastii jagiellońskiej, nie pomijając wielkiego księcia Witolda. Artykuł IV określa chłopów jako stan, który „najliczniejszą w narodzie stanowi ludność, a zatem najdzielniejszą kraju siłę" [Konstytucja 3 Maja 1791, J. Kowecki (oprac.), Warszawa 1991]; Uzupełnieniem „Ustawy rządowej”, określającym istotę relacji Korony i Wielkiego Księstwa Litewskiego, było, podpisane 22 października 1791 r., „Zaręczenie Wzajemne Obojga Narodów". 
To specyfika czasów, w jakich żył Ogiński, i paralelna z nimi specyfika tożsamości narodowej, umożliwia nadawanie tej postaci rangi wspólnego bohatera. Okres okołokonstytucyjny przyniósł przełom w mentalności tego magnata, jak i prawdopodobnie wielu innych obywateli, otwartych na przyjęcie założeń Ustawy rządowej. Był to moment zespolenia poczucia przynależności szlacheckiej z przynależnością ogółu społeczeństwa. Ostatnia dekada XVIII wieku zapoczątkowała proces ontogenezy tożsamościowej, której nie było dane postępować w sposób naturalny, ze względu na politykę państw zaborczych. Postać o świadomości obywatelskiej, która przeżyła tak burzliwe dzieje, bez żadnej trudności utożsamiała się ze wszystkimi „Polakami”, jak również w szczególności z Litwinami, a zespolenie $w$ jedną całość różnych ujęć tożsamościowych na drodze przywrócenia wspólnego państwa przedkładała nad kwestię jego przyszłego władcy.

Choć Ogiński nie gości w panteonie polskich bohaterów narodowych, jest bardzo ceniony w środowiskach muzycznych za pozostawione po sobie utwory, wśród których dominują polonezy i romanse na fortepian. Nadanie tej postaci należnej jej rangi w pamięci kulturowej współczesnego społeczeństwa polskiego, zapoznanie Polaków szerzej z jego bogatą i ciekawą biografią oraz z dążeniami do przywrócenia „Polski” byłoby zaledwie pierwszym krokiem na drodze do poprawy relacji polsko-litewskich. Po upowszechnieniu Michała Kleofasa jako bohatera, musiałoby nastąpić umiejscowienie go w początkowej fazie "naszych” (aktualnych) czasów jako działacza z XIX wieku, przy równoczesnym odrzuceniu nadinterpretacji o zdradzie ojczyzny. Dopiero stając się bohaterem faktycznym i uniwersalnym, zwłaszcza zaś - zarówno polskim, litewskim, jak i białoruskim - osoba księcia może przyczynić się do osłabienia stereotypu obcości między tymi narodami. Powyższy artykuł był próbą wstępnej i cząstkowej rehabilitacji kulturowej dziedzictwa I Rzeczypospolitej.

\section{BIBLIOGRAFIA}

Ant sutarties stalo stovejjo kryžius. L. Želigovskio agresija turi būti įvertinta, Voruta, 1824.02.1993, 7.

Basanavičius J., "Aušra” i „Dziennik Poznański”, [w:] B. Kalęba, M. Zaczyński, Wkregu sporów polsko-litewskich na przełomie XIX i XX wieku. Wybór materiałów, tom 1, Wydawnictwo Uniwersytetu Jagiellońskiego, Kraków 2004.

Czapliński P., Obirek S., Bohater, [w:] Modi memorandi. Leksykon kultury pamięci, red. M. Saryusz-Wolska, R. Traba, Wydawnictwo Naukowe Scholar, Warszawa 2014.

Iłłakowiczówna K., Ballady bohaterskie, Wydawnictwo Zakładu Narodowego im. Ossolinskich, Lwów 1934. 
Julkowska V., O roli historii i pamięci w kreowaniu bohaterów przeszłości. Wprowadzenie, [w:] Jan Kiliński. Historia i pamięć, red. V. Julkowska, Instytut Historii UAM, Stowarzyszenie Miłośników Zabytków Historycznych, Poznań - Trzemeszno 2015.

Kalęba B., Zaczyński M., Wkręgu sporów polsko-litewskich na przełomie XIX i XX wieku. Wybór materiatów, Kraków 2004.

Kiaupa Z., Litwa w dwudziestym wieku. Republika Litewska w latach 1918-1940, Projekt: Historia a teraźniejszość. Dziedzictwo Rzeczpospolitej Obojga Narodów a aktualne stosunki polsko-litewskie, Instytut Europy Środkowo-Wschodniej, Lublin 2012.

List Ogińskiego do Rymkiewicza z 6 grudnia 1796 r., [w:] W. Smoleński, Emigracya polska w latach: 1795-1797: (materyaty historyczne), Przegląd Historyczny, 1910, 11/3.

Literatūrairmenas, 08.04.1989, 15.

Łaszkiewicz H., Pamięć i zapomnienie. Węzty pamięci w stosunkach polsko-litewskich, Instytut Europy Środkowo-Wschodniej, Lublin 2012.

Miknys R., Litwini wobec Polski i Polaków: Spojrzenie na podstawie badań nad historia Polski w XX wieku w historiografii litewskiej ostatniego dwudziestolecia, Instytut Europy Środkowo-Wschodniej, Lublin 2012.

Saryusz-Wolska M., Traba R. (red.), Modi memorandi. Leksykon kultury pamięci, Wydawnictwo Naukowe Scholar, Warszawa 2014.

Smoleński W., Emigracya polska w latach: 1795-1797: (materyały historyczne), Przegląd Historyczny, 1910, 11/3.

Srebrakowski A. (oprac.), My nie bracia, my sąsiedzi. Polska perspektywa stosunków polsko-litewskich. Wybór tekstów i dokumentów, Kolegium Europy Wschodniej im. Jana NowakaJeziorańskiego, Wrocław 2013.

Srebrakowski A., Recenzja podręczników, Telsze 2016.

Szpociński A., Formy przeszłości a komunikacja społeczna, [w:] A. Szpociński, P.T. Kwiatkowski, Przeszłość jako przedmiot przekazu, tom I, Seria: Współczesne Społeczeństwo Polskie wobec Przeszłości, Instytut Studiów Politycznych PAN, Wydawnictwo Naukowe Scholar, Warszawa 2006.

Szpociński A., Przeszłość a środki przekazu, [w:] A. Szpociński, P.T. Kwiatkowski, Przeszłość jako przedmiot przekazu, tom I, Seria: Współczesne Społeczeństwo Polskie wobec Przeszłości, Instytut Studiów Politycznych PAN, Wydawnictwo Naukowe Scholar, Warszawa 2006.

Szpociński A., Kwiatkowski P.T., Przeszłość jako przedmiot przekazu, tom I, Seria: Współczesne Społeczeństwo Polskie wobec Przeszłości, Instytut Studiów Politycznych PAN, Wydawnictwo Naukowe Scholar, Warszawa 2006.

Šapoka M., Wielkie Księstwo Litewskie: próba nowego spojrzenia na punkty styczne polskiej i litewskiej pamięci historycznej, Projekt: Historia a teraźniejszość. Dziedzictwo Rzeczpospolitej Obojga Narodów a aktualne stosunki polsko-litewskie, Instytut Europy Środkowo-Wschodniej, Lublin 2012.

Truska L., Antanas Smetona ir jo laikai, Valstybinis leidybos centras, Vilnius 1996.

Załuski A., Michat Kleofas Ogiński. Życie, działalność i twórczość, Polska Fundacja Kulturalna, Londyn 2003.

Żenkiewicz J., Litwa na przestrzeni wieków i jej powiązania z Polska, Uniwersytet Mikołaja Kopernika, Torun 2001.

\section{Źródła}

Additions a mes memoires oraz Observations sur les evenements arrives en Pologne depuis la fin de novembre 1830, Rosyjskie Państwowe Archiwum Akt Dawnych, Moskwa. 
Brazauskas J., Historia Litwy od czasów najdawniejszych do unii lubelskiej, przekł. Ł. Pocewiczienie, Kowno 1995.

„Dziennik Poznański”, 1883, nr 231.

Kowecki J. (oprac.), Konstytucja 3 Maja 1791, Państwowe Wydawnictwo Naukowe, Warszawa 1991.

Ogiński M.K., Pamiętniki o Polsce i Polakach od r. 1788 aż do końca r. 1815, nakładem księgarni Jana Konstantego Żupańskiego, Poznań 1870.

Wyciag z historyi Napoleona $i$ wielkiej armii przez p. generała hr. de Segur, tom I s. 150-157. Szóste wydanie.

\section{Materiały zdigitalizowane}

Akińczo A., Litwa: rozpocząt się Międzynarodowy Festiwal im. Michała Ogińskiego, https://dzieje.pl/kultura-i-sztuka/litwa-rozpoczal-sie-miedzynarodowy-festiwal-im-michala-oginskiego, [dostęp: 11.02.2019, godz. 15:00].

http:/ /124.lt/ pl/kultura-pl/item/51052-w-wilenskim-ratuszu-inauguracja-roku-michala-kleofasa-oginskiego, [dostęp: 11.02.2019, godz. 16:03].

http:/ /zw.lt/ kultura-historia/odsloniecie-pomnika-rodu-oginskich-w-retowie/, [dostęp: 11.02.2019, godz. 15:11].

https://dzieje.pl/kultura-i-sztuka/litwa-rozpoczal-sie-miedzynarodowy-festiwal-im-michala-oginskiego, [dostęp: 11.02.2019, godz. 15:00].

https://nowahistoria.interia.pl/aktualnosci/news-vytautas-landsbergis-pilsudski-to-wasz-bohater-popelnil-jedn,nId,2236986, [dostęp: 7.02.2019, godz. 13:46].

https://www.ludzkosc.pl/Petras_Rimsa, [dostęp: 7.02.2019, godz. 10:11].

Kurier Wileński, https:/ / kurierwilenski.lt/2017/07/14/korzenie-wspolczesnosci-dzienniki-michala-romera-z-lat-1911-1915/, [dostęp: 7.02.2019, godz. 10:06].

Łukaszewicz B., UWAGI o litewskim podręczniku do nauki historii dla klasy jedenastej, https://www.upc.smm.lt/ekspertavimas/vadoveliai/komisija/2015-metai/Istorijos-vadovelio-11-klasei-recenzija-lenku-kalba-2015.docx., [dostęp: 8.02.2019, godz. 15:58].

Maciejewski M., Marszał M., Sadowski M. (red.), Tendencje rozwojowe myśli politycznej $i$ prawnej, Wrocław 2014, http://www.repozytorium.uni.wroc.pl/dlibra/publication/46592/edition/46519/content?ref=desc, [dostęp: 8.02.2019, godz. 10:05].

Mackiewicz M., Obraz litewskiego odrodzenia narodowego w publicystyce "A uszry" w latach 18831886, [w:] Tendencje rozwojowe myślipolityczneji prawnej, red. M. Maciejewski, M. Marszał, M. Sadowski, Wydział Prawa, Administracji i Ekonomii Uniwersytetu Wrocławskiego, Wrocław 2014, s. 423, http:/ / www.repozytorium.uni.wroc.pl/dlibra/publication /46592/edition/46519/content?ref=desc, [dostęp: 8.02.2019, godz. 10:05].

Odsłonięcie pomnika rodu Ogińskich w Retowie, http://zw.lt/kultura-historia/odsloniecie-pomnika-rodu-oginskich-w-retowie/, [dostęp: 11.02.2019, godz. 15:11].

Petras Rimsa, https:/ / www.ludzkosc.pl/Petras_Rimsa, [dostęp: 7.02.2019, godz. 10:11].

Sidorkiewicz J., Korzenie wspótczesności. Dzienniki Michała Römera z lat 1911-1915, https:/ / kurierwilenski.lt/2017/07/14/ korzenie-wspolczesnosci-dzienniki-michala -romera-z-lat-1911-1915/, [dostęp: 7.02.2019, godz. 9:51].

Šimelionis I., Vilnija šimtmečio verpetuose, Lietuvių literatūros ir tautosakos institutas, Vilnius 2002.

Szpunar K., Kazimiery Iłłakowiczówny dyskurs o utraconej ojczyźnie, [w:] Tematy i konteksty. Pogranicza jako przestrzenie... konfliktów: zło konieczne?, 2017, 7(12), http://ifp.univ. rzeszow.pl/tematy_i_konteksty/tematy_i_konteksty_12/11_szpunar.pdf, [dostęp: 7.02.2019, godz. 22:04]. 
Vytautas Landsbergis: "Piłsudski to wasz bohater. Popetnit jednak ciężkie błędy", https://nowahistoria.interia.pl/aktualnosci/news-vytautas-landsbergis-pilsudski-to-waszbohater-popelnil-jedn,nId,2236986, [dostęp: 7.02.2019, godz. 13:46].

W wileńskim ratuszu - inauguracja Roku Michała Kleofasa Ogińskiego, http://124.lt/pl/kultura-pl/item/51052-w-wilenskim-ratuszu-inauguracja-roku-michala-kleofasa-oginskiego, [dostęp: 11.02.2019, godz. 16.03].

Wileńskie Rozmaitości, III kwartał 1990, nr 3, Towarzystwo Miłośników Wilna i Ziemi Wileńskiej - Oddział w Bydgoszczy, s. 2, http://www.kpbc.ukw.edu.pl/dlibra/plaincontent?id=23060, [dostęp: 7.02.2019, godz. 21:45]. 